\title{
Plazas para los antepasados: Descentralización y poder corporativo en las formaciones políticas preincaicas de los Andes circumpuneños
}

Axel E. NieLSEN ${ }^{1}$

\section{RESUMEN}

En este artículo sostenemos que entre las sociedades circumpuneñas del Período de Desarrollos Regionales Tardio (1250-1430 DC) se encontraban ya presentes varias de las prácticas de gobierno descentralizado y apropiación corporativa de recursos observadas en los Andes por los invasores europeos en el siglo XVI. Para fundamentar esta propuesta, partimos considerando algunas prácticas políticas vinculadas con la integración segmentaria y el culto a los antepasados documentadas etnohistóricamente, poniendo énfasis en las expresiones materiales asociadas. Luego se presentan los resultados de investigaciones arqueológicas realizadas en las plazas y estructuras asociadas de dos grandes conglomerados circumpuneños del siglo XIV -Los Amarillos (quebrada de Humahuaca) y Laqaya (Norte de Lípez)- demostrando la presencia de evidencias derivadas de aquellas prácticas.

Palabras claves: Período de Desarrollos Regionales - Humahuaca - Lípez - culto a los antepasados - chullpas - prácticas corporativas - complejidad social.

\begin{abstract}
We propose that several practices of decentralized government and corporate resource appropriation observed in the Andes by the European conquerors in the 16th century were already present among Circumpuna societies during the Late Regional Developments Period (AD 1250-1430). To support this statement, we begin by considering some ethonhistorically documented political practices related to segmentary integration and ancestor veneration, putting emphasis on some of the material correlates that could be associated with them. Then, we present the results of archaeological research conducted in the plazas and associated structures of two large Circumpuna, nucleated settlements that were used during the $14^{\text {th }}$ century-Los Amarillos (quebrada de Humahuaca) and Laqaya (North Lipez)- demonstrating the presence of evidences derived from those practices.
\end{abstract}

Key words: Regional Developments Period - Humahuaca - Lipez - ancestor worship - chullpas - corporative practices - social complexity.

Recibido: septiembre 2005. Aceptado: febrero 2006.

1 CONICET - Instituto Interdisciplinario Tilcara, Universidad de Buenos Aires, Tilcara. Casilla de Correo 14 (4624) Tilcara, ARGENTINA. Email: anielsen@arnet.com.ar

\section{Introducción}

Pocos investigadores cuestionarían la idea de que el tránsito, durante los primeros siglos del segundo milenio DC, entre el Período Medio o Formativo Tardío y el Período Intermedio Tardío o de Desarrollos Regionales, implicó cambios sociales profundos en la mayoría de los pueblos circumpuneños. Menos acuerdo existe, sin embargo, en cuanto a la interpretación de estos cambios. Específicamente, ¿qué diferencias existen entre las formaciones económicas y políticas de fines del primer milenio DC y las que caracterizaban a estos pueblos al momento de la expansión incaica? ¿Se trata simplemente de cambios en la escala (demográfica, territorial, productiva) de estas organizaciones, o se trata de una transformación más profunda, del modo en que se relacionan las personas y se constituyen las colectividades? Evidentemente, estamos lejos aún de contar con la evidencia necesaria para responder a estas preguntas, por lo que nuestro propósito aquí es sólo contribuir a la reflexión sobre el tema a través de la discusión de las prácticas desarrolladas en los espacios públicos de algunos de los grandes conglomerados habitacionales circumpuneños del Período de Desarrollos Regionales. Elegimos esta entrada al problema bajo la sencilla premisa de que lo que la gente hace en el espacio público guarda una estrecha relación con las instituciones y representaciones que rigen la vida política de la comunidad y estructuran el espacio social en su conjunto (sensu Bourdieu 1980).

Como lo señalaron hace tiempo Madrazo y Ottonello (1966), algunas de las manifestaciones arqueológicas más dramáticas de las transformaciones sociopolíticas aludidas al comienzo se encuentran en los asentamientos, que -sobre todo en las regiones con economías agrícolas- aumentan rápidamente su tamaño y concentración edilicia, además de trasladarse a emplazamientos de valor defensivo. Otra novedad que muestran 
los poblados de esta época es la aparición de espacios públicos de reunión claramente definidos. A veces estas "plazas" 2 aparecen como grandes áreas despejadas que se recortan claramente contra la densa red de edificación de los conglomerados (p.e., Tastil en el Toro, Juella en Humahuaca, Cruz Vinto en el Norte de Lípez), en otros casos se trata de recintos de forma irregular encerrados por muros, pero de excepcional tamaño (Los Amarillos en Humahuaca, Laqaya en el Norte de Lípez). Algunos se encuentran cerca del centro geométrico de los sitios, mientras que otros se ubican hacia los bordes (Volcán en Humahuaca, Doncellas en la puna) o hasta segregados del núcleo habitacional (Likán en el Loa Superior), aprovechando elevaciones naturales del terreno. A menudo se asocian a los principales accesos o se constituyen en nodos donde convergen las redes de circulación interna de los poblados. Estas propiedades, como capacidad excepcional en relación al contexto edilicio, alta visibilidad (tanto exposición como dominio visual en relación a las instalaciones) y centralidad en las redes de circulación, permiten afirmar que las plazas constituían elementos destacados en la experiencia cotidiana de las comunidades de la época.

Los espacios públicos no se presentan en todos los conglomerados preincaicos, sino aparentemente sólo en los de mayor tamaño relativo para cada región. Más aún, algunos de los poblados de mayor envergadura (Tastil, Los Amarillos) parecen contar con varias plazas de distintos tamaños y características, que suponemos afectas a diversas

2 Para simplificar la terminología, nos referiremos a estas áreas como "espacios públicos" -aunque entendemos que existen otros tipos de espacios públicos formal y funcionalmente diferentes como, por ejemplo, las propias vías de circulación o sectores defensivos de los pucaras, por mencionar sólo algunos- o "plazas," tomando en este último caso como referencia la definición formal que ofrece la Real Academia Española (2001: 1784): “(Del lat. vulg. *platt_a). f. Lugar ancho y espacioso dentro de un poblado, al que suelen afluir varias calles", sin adoptar supuestos sobre su función o significado. El uso del adjetivo "público" sólo se refiere a que, dada su gran capacidad y accesibilidad, es razonable inferir que fueron espacios diseñados para ser ocupados por gran número de personas; no pretendemos transponer al pasado andino las connotaciones que la oposición "público-privado" asume en nuestra propia cultura. En otros trabajos (Nielsen 1996a) hemos empleado en este sentido "espacios de ocupación comunitaria," expresión que preferimos no utilizar ahora para no complicar innecesariamente el texto. actividades. La distribución diferencial de estos espacios y su aparente correlación con el tamaño de las comunidades asociadas nos llevó hace tiempo a ver en los espacios públicos un principio de diferenciación de los asentamientos y una expresión del surgimiento de estructuras políticas multicomunitarias de una escala sin precedentes e internamente jerarquizadas, al menos en términos del control diferencial que ejercían ciertos sectores sobre prácticas y situaciones de importancia pública (Nielsen 1996b, 2002).

En esta oportunidad queremos dar un paso más, buscando precisar cuáles fueron algunas de estas prácticas políticas y lo que implican para entender la organización y dinámica de las formaciones sociales que se constituyeron en los Andes circumpuneños durante los primeros siglos del segundo milenio de nuestra era. Con este objetivo, en las próximas páginas presentamos y discutimos los resultados de investigaciones realizadas en dos espacios públicos insertos en dos grandes conglomerados que parecen haber alcanzado su máximo tamaño y complejidad en el siglo XIV, en vísperas de la conquista incaica: Los Amarillos en la quebrada de Humahuaca y Laqaya en el Norte de Lípez. ${ }^{3}$

El trabajo se desarrolla en seis secciones principales. En la primera se reseñan algunas características de las formaciones sociales de orientación corporativa o comunal compleja. La segunda y tercera destacan datos proporcionados por la etnohistoria y la etnografía sobre la existencia de prácticas entre los pueblos surandinos que nos remiten a algunas de estas formas organizativas, generando a partir de ellas algunas expectativas

3 Designamos "Norte de Lípez" a la región arqueológica correspondiente al salar de Chiguana y la porción sur de la cuenca de Uyuni, que como región ecológica se distingue del resto del altiplano al sur del gran salar por ser la única que permite el desarrollo de una agricultura económicamente significativa (Nielsen 1997). Es preciso señalar, sin embargo, que en la literatura y documentación históricas el "norte de Lípez" abarca comunidades situadas al norte del Salar, como Llica y Tahua. Esta diferencia podría suscitar confusiones, pero hay que tener en cuenta que antes de nosotros Lecoq (1999) ya había englobado las tierras al norte del salar de Uyuni -donde había investigado- en lo que llamó "Región Intersalar". Esta distinción tiene, además, relevancia arqueológica, ya que existen diferencias entre la cultura material de los sitios prehispánicos tardíos de la margen norte y sur del salar de Uyuni. 
respecto al uso de los espacios públicos. La cuarta y quinta sección presentan sintéticamente los resultados de las investigaciones arqueológicas realizadas en los dos sitios mencionados. En el apartado final se discute el significado que podrían tener los datos presentados a la luz de las propuestas teóricas y etnohistóricas delineadas al comienzo.

\section{Modos de integración y unidades de apropiación}

Hace tiempo ya, McGuire (1983) señaló la importancia de tratar con independencia analítica distintos aspectos de la complejidad social, identificando a la heterogeneidad y a la desigualdad como dos dimensiones fundamentales de este fenómeno. Durante la última década, la literatura sobre formaciones sociales de orientación corporativa (Blanton et al. 1996; Feinman 2000) o comunal (McGuire y Saitta 1996) ha puesto de relieve dimensiones de variabilidad más específicas ignoradas por los modelos neoevolucionistas sobre el surgimiento de las jefaturas (Earle 1997) y la desigualdad social (Hayden 2001), que han privilegiado la consideración de prácticas políticas de orientación individualista y basadas en la exclusión social. Teniendo en cuenta que el pensamiento neoevolucionista ha ejercido una verdadera "hegemonía heurística" en la arqueología surandina desde la década de 1970, la reflexión teórica sobre las formaciones corporativas cobra especial importancia, ya que nos ofrece la posibilidad de pensar las sociedades prehispánicas del área desde una óptica diferente.

En su artículo sobre "teoría procesual-dual" Blanton y colaboradores (1996), retomando aportes de numerosos autores anteriores, caracterizan a las sociedades corporativas por oposición a las sociedades "de red" (network). Estas dos "estrategias" o "modos de acción política" representarían extremos en un eje de variación continua que intersectaría "perpendicularmente" al de igualdadjerarquía (Feinman 2000: 32), definiendo así una dimensión independiente para el análisis de la diversidad en formaciones sociales con distinto grado de complejidad. Una consideración detallada de esta propuesta, pone en evidencia que el continuo "de red-corporativo" comprende en realidad distintos aspectos que, a falta de argumentos que establezcan su relación y posible interdependencia, convendría tratar como variables organizativas diferentes. Interesa aquí destacar dos de estas dimensiones, que podríamos denominar el modo de integración política (centralizado-descentralizado) y las unidades sociales de apropiación de recursos (individuos-grupos). La consideración de estas y otras variables permite llevar la reflexión más allá del problema de decidir si una sociedad determinada es más o menos desigual o compleja hacia la investigación de las múltiples formas que puede asumir esa desigualdad o complejidad.

Por "modo de integración política" nos referimos a la distribución de las capacidades de decisión sobre asuntos de interés colectivo entre los integrantes de una unidad política discreta. En un extremo, estas pueden concentrarse en un individuo o grupo (centralización), mientras que en el otro se encontrarían dispersas entre muchos o todos los miembros de la colectividad (descentralización), requiriéndose la concertación de múltiples voluntades para la toma de decisiones de interés común. El modo de integración podría pensarse como un aspecto de la desigualdad que compromete a la distribución del poder político, pero teniendo en cuenta que la circulación de esta forma de capital posee una dinámica distintiva (Bourdieu 1991) conviene analizarlo como un campo de acción diferente a los que se constituyen en torno a la circulación de capitales económicos o culturales. Como tal, interesa no sólo describir su forma en un caso determinado (p.e., su grado de centralización relativa), sino las estrategias o prácticas concretas a través de las cuales los actores negocian la distribución de recursos en cuestión.

Los arreglos institucionales -como las prácticas socialmente reproducidas y cosmológicamente legitimadas (Douglas 1986: 46)- que permitirían sostener un orden descentralizado, aun en el caso de Estados y otras sociedades complejas, son muy variados. Algunos ejemplos que han sido mencionados en la literatura sobre formaciones corporativas incluyen: el gobierno mediante concertación de todos los miembros de la colectividad (asambleas) o de representantes de todas las unidades sociales que la componen; el énfasis en el comportamiento (moral o ritualmente) ejemplar como condición del gobernante y mecanismos de comunicación reflexiva que sometan regularmente las autoridades a evaluación pública; la retención de facultades políticas (p.e., nombrar o fiscalizar 
autoridades, ciertas decisiones) por parte de las unidades sociales de orden inferior en la estructura y la participación activa de estas unidades en el ceremonial público y en el control de otros ritos de importancia para la reproducción cultural del grupo. En ausencia de instituciones centrales con suficiente poder para prevenir coactivamente la fisión de las unidades constitutivas, las formaciones políticas descentralizadas se caracterizan también por la vigencia de prácticas tendientes a reforzar la identidad y cohesión del conjunto. Entre ellas se encuentra el énfasis en expresiones rituales y códigos cognitivos ampliamente compartidos, así como en el uso de materialidades comunes (arquitectura, vestimenta, elementos de uso cotidiano) que refuerzan la experiencia de pertenecer a una misma comunidad (Blanton et al. 1996; Blanton 1998: 154-170; Feinman 2000).

Si bien la descentralización ha sido reiteradamente señalada como un atributo de las sociedades "corporativas" o "comunales", estos últimos conceptos no se refieren tanto a la distribución del poder político (o de otro tipo) en la sociedad en su conjunto como al tipo de unidad social, donde residen estas capacidades o en el control de los recursos que las sustentan. Mientras que en las sociedades de red son los individuos quienes se apropian directamente los recursos (bienes suntuarios o de subsistencia, conocimiento, lealtades, prestigio) en las sociedades corporativas estos se encuentran en poder de grupos, pudiendo usufructuarlos los individuos sólo en virtud de su pertenencia a determinadas colectividades. La dimensión individual-corporativa, como eje de tensión o negociación propia de toda organización política, se define por la confrontación de dos tipos de estrategias: una de ellas articulada en torno a los intereses individuales de los actores, la otra a partir de intereses o proyectos compartidos por conjuntos de personas.

Las prácticas que mantienen el control corporativo sobre distintos tipos de capital son también diversas, pero generalmente incluyen cierta represión o enmascaramiento de la identidad y otras expresiones individuales a favor de los referentes colectivos, lo que resulta en cierto "anonimato del poder". Esto se refleja, por ejemplo, en la escasa importancia que revisten en estas formaciones el consumo conspicuo y otras formas de glorificación de los gobernantes o miembros de la élite (los indicadores arqueológicos más utilizados para argumentar sobre el surgimiento de sociedades complejas), que ceden paso a ceremonias públicas centradas en principios cosmológicos inclusivos, con énfasis en la redistribución, en los emblemas de mando y en los códigos cognitivos que sustentan el orden social. Si existen jerarquías, estas no privilegian a individuos, sino a grupos o categorías de personas definidas por descendencia, ocupación, etnicidad o algún otro criterio.

\section{Integración segmentaria y apropiación corporativa en los Andes}

Como es sabido, durante las últimas décadas la arqueología andina ha hecho amplio uso de modelos etnohistóricos y etnográficos para interpretar la economía de las sociedades prehispánicas, pero salvo contadas excepciones (p.e., Aldunate y Castro 1981; Castro et al. 1984; Schiappacasse y colaboradores 1989), apenas ha explorado las posibilidades de estas fuentes de información para modelar las estructuras y prácticas políticas pretéritas. Recién durante la última década se advierte entre los arqueólogos un interés por desarrollar más sistemáticamente esta línea de investigación (p.e., Albarracín 1996; Isbell 1997). La consideración de las sociedades andinas históricas es importante para nuestro argumento, ya que permite relacionar algunos de los arreglos institucionales recién delineados en forma genérica con prácticas específicas, comenzando así a visualizar las evidencias arqueológicas que podrían resultar de ellos. Como el tema ha sido recientemente tratado en la literatura, nos limitaremos aquí a hacer una reseña selectiva ${ }^{4}$ con el único propósito de generar expectativas respecto al uso de los espacios públicos que sirvan como marco de referencia para la interpretación de los datos arqueológicos.

\footnotetext{
4 Esta síntesis combina referencias a la organización de grupos quechua y aymara hablantes de diversas regiones, pasando por alto importantes diferencias entre ellos. Así, por ejemplo, el término ayllu posee connotaciones muy diversas según el lugar, enfatizando en algunos casos los aspectos territoriales, en otros, el parentesco. Nuestro propósito, sin embargo, no es describir las prácticas políticas de un grupo particular, sino extraer algunos principios organizativos generales vigentes en distintas partes de los Andes a la llegada de los europeos para utilizarlos como hipótesis cuya pertinencia para la interpretación de casos particulares será evaluada arqueológicamente.
} 
La etnohistoria indica que muchos de los "señoríos étnicos" encontrados por los europeos en los Andes en el siglo XVI respondían a una estructura segmentaria ${ }^{5}$ en la que se reconocen algunas de las formas de gobierno descentralizado y de apropiación corporativa mencionadas anteriormente. Las organizaciones segmentarias se caracterizan por la yuxtaposición de unidades semejantes que retienen su identidad y autonomía relativa, aunque subordinándose a una estructura política mayor. En el caso andino, esas unidades eran los ayllus, que se agrupaban formando niveles de gestión crecientemente inclusivos (ayllus menores, mayores, mitades, grupos étnicos, confederaciones) cada uno de ellos a cargo de autoridades o curacas (jilaqatas, mallku, qhapaq mallku), acompañados a menudo por "segundas personas", cuyas atribuciones abarcaban desde el cogobierno hasta el reemplazo o sucesión (Platt 1987: 73). Al menos en los niveles superiores de la estructura, estas autoridades eran provistas exclusivamente por ciertos ayllu o "casas principales" (Platt 1987; Izko 1992; Pärssinen 1992). Como responsables de las funciones de gobierno y el culto a las huacas, los curacas percibían servicios, transformando de este modo sus privilegios políticos en formas excepcionales de apropiación del trabajo comunitario. A pesar de estas desigualdades estructurales, cada "parcialidad" retenía el control sobre los medios de producción básicos (la tierra y la fuerza de trabajo), el derecho a nombrar o fiscalizar las autoridades locales y la devoción a sus huacas. Se combinaban de este modo instituciones de gobierno centralizadas-jerárquicas con otras descentralizadas-heterárquicas en el seno de las mismas formaciones políticas.

Como sucede en otras sociedades segmentarias (Kuper 1982), la identidad de los ayllus se fundaba en dos lógicas indisolublemente unidas: una territorial, otra de parentesco. De acuerdo a la primera de ellas, los miembros del ayllu eran personas que administraban corporativamente la tierra y otros recursos estratégicos asociados a ella, como el agua o las pasturas (Rasnake 1989: 54; Izko 1992: 47-48). Según la lógica del parentesco, eran descendientes de antepasados comunes,

5 Ha sido mérito de Albarracín $(1996,1997)$ llamar la atención sobre las posibilidades del modelo de organización segmentaria para la interpretación de las estructuras políticas prehispánicas en los Andes. reales o míticos, que se consideraban propietarios últimos de la tierra y fuentes de toda autoridad. En este sentido, la memoria de los antepasados actuaba como sustento ideológico de la identidad, autonomía y autarquía relativas de cada ayllu dentro de la estructura política mayor. Esta misma lógica, sin embargo, operaba también como justificación de las jerarquías políticas. El derecho de cada linaje o ayllu a proveer las autoridades y a percibir los tributos correspondientes se relacionaba con la posición que ocupaba su ancestro fundador en una jerarquía que abarcaba no sólo a los antepasados, sino a otras huacas o entidades sobrenaturales, cuyas relaciones también se entendían de acuerdo a la lógica del parentesco, como una cadena de descendencia entre deidades. Los informes de los extirpadores de idolatrías, como el Padre Arriaga (1968 [1621]: 22-32), por ejemplo, reconocen una jerarquía de cuatro rangos:

1. El sol (Punchao o Inti), la luna (Quilla), ciertas estrellas (p.e., las Pléyades u Oncoy), el rayo (Libiac o Illapa) y la tierra (Mamapacha).

2. Pacarinas, lugares de origen de cada grupo venerados en forma de cerros destacados (Mallkus), lagos o grandes rocas.

3. Malquis o "huesos o momias de sus ancestros paganos, que llaman los hijos de las huacas".

4. Rocas de formas singulares o conopas, considerados ídolos o deidades del mundo doméstico.

También existían diferencias de rango entre los propios antepasados. Las tradiciones orales explicaban cómo estas asimetrías derivaban de jerarquías de origen, relaciones de parentesco entre malquis o habían surgido en el curso de acontecimientos bélicos, cuando ciertas huacas habían establecido su supremacía sobre otras o conquistado nuevos territorios. ${ }^{6}$ Estas tradiciones incluían también información sobre la distancia genealógica que presuntamente separaba a linajes y parcialidades específicas de aquellas entidades ances-

6 Este punto establece una conexión directa, al menos a nivel de la memoria colectiva, entre las antiguas guerras y el surgimiento de asimetrías políticas propias de las organizaciones segmentarias, como lo propone Platt 1987 (Nielsen 1996b, 2002). 
trales. Se completaba así una lógica que conjugaba argumentos históricos -contingencias míticasy genealógicos para anclar las desigualdades sociales -así como sus limitantes institucionales- en un modelo cosmológico ampliamente compartido.

Es importante destacar que las jerarquías que apuntalaba esta ideología estaban referidas a grupos antes que a individuos. A diferencia de lo que sucede con la veneración a los antepasados en sociedades de red (p.e., entre los Mayas clásicos [McAnnany 1995]), en los Andes la memoria de los ancestros operaba como una forma de "despersonalización" de la autoridad, cuyos poderes no estaban necesariamente ligados a la persona del dirigente (sus méritos, sus contactos), sino que residían en la huaca o antepasado -el referente mítico del grupo- que el individuo que actuaba como curaca encarnaba contingentemente a partir de las ceremonias de investidura y la posesión de los emblemas (J. L. Martínez 1995). La apropiación corporativa del poder se mantenía, además, a través de arreglos institucionales que obligaban a los individuos que ejercían funciones políticas a negociar constantemente con los demás miembros del linaje o ayllu (Platt 1987; Pease 1992). Primero, porque la selección de los curacas no resultaba de la aplicación automática de una norma (p.e., primogenitura), sino que dependía de un consejo de mayores que juzgaban las aptitudes de diversos candidatos. Segundo, porque las decisiones y movilización de excedentes requerían del concurso tanto de las autoridades inferiores y superiores de la estructura segmentaria como de sus pares (segundas personas, líderes de otras mitades o ayllus).

\section{Prácticas segmentarias y corporativas en el espacio público}

Acabamos de argumentar que, en el siglo XVI, el culto a los antepasados proporcionaba la lógica cultural en que se fundaban (y negociaban) los aspectos tanto jerárquicos como descentralizados y corporativos de las formaciones políticas andinas. Si esto es así, la investigación de los orígenes y variaciones organizativas que experimentaron estas prácticas ofrecería una importante vía para rastrear la historia de estas instituciones y su diversidad regional. La arqueología ofrece una vía de acercamiento privilegiada a estos matices de la práctica, ya que sus evidencias son consecuencia directa de la acción pasada en toda su especi- ficidad. Puesto que las referencias etnohistóricas y etnográficas indican que la veneración de los ancestros comprometía con frecuencia al espacio público, las plazas se convierten en contextos privilegiados para una exploración de este tipo. En este caso tomaremos en cuenta tres líneas de evidencia que podrían relacionar directamente las actividades, estructura y contenido de las plazas con la veneración a los antepasados y con las formas organizativas hasta aquí consideradas: la materialidad de los ancestros, la espacialidad segmentaria manifiesta en el ámbito público y la importancia de las fiestas comunitarias en la reproducción del grupo y su estructura (Saignes 1993: 60).

La piedra angular del culto a los antepasados reside en una serie de prácticas que permiten a los difuntos y otras entidades "ancestrales" interactuar con los vivos. A través de ellas, estas deidades contribuyen a naturalizar la arbitrariedad de las relaciones de poder, no sólo por referencia a un orden (más o menos asimétrico) que existió en un pasado mítico, sino convirtiendo ese orden en un hecho actual, al incorporarse ellas mismas a la experiencia cotidiana de las personas. Para ello, estos cultos involucran siempre metonimias o materialidades duraderas (lugares, objetos) que actúan como referentes empíricos de los difuntos o se experimentan como "animadas por su agencia" (Meskell 2004; Nielsen 2006).

En los Andes el principal referente del ancestro era el cuerpo del difunto o partes de él (la momia, los huesos o fardos conteniendo restos de cabellos o recortes de uñas). El alma de los antepasados, sin embargo, también habitaba en otras materialidades, incluyendo imágenes o figurinas ("ídolos"), máscaras, ciertos textiles, monolitos, sepulcros, afloramientos rocosos de apariencia singular y ciertas geoformas, como los cerros prominentes o las cuevas (Kaulicke 2001). Isbell (1997) ha argumentado que los "sepulcros abiertos" (monumentos mortuorios que permitían a las personas acceder regularmente a su contenido) eran tan significativos como los propios malquis en la veneración de los antepasados andinos. Esta idea se encontraría avalada por los testimonios escritos de la Conquista, que abundan en referencias a la dedicación puesta por los andinos en la confección y mantenimiento de los sepulcros de sus antepasados (Cieza de León 1996 [1553]: Cap. C). Puesto que estas estructuras se preservan me- 
jor que los cuerpos y a menudo sobrevivieron la extirpación de idolatrías, Isbell concluye que los sepulcros abiertos constituyen el mejor indicador arqueológico del surgimiento de formas de organización comparables al ayllu etnohistórico. Basándose en una amplia revisión de casos, enumera una serie de atributos arquitectónicos que ayudarían a reconocer los sepulcros abiertos, aunque en ausencia de restos humanos no considera que ninguno de ellos sea condición necesaria o suficiente para atribuir esta función a una estructura. Entre ellos, nos interesa destacar la calidad de la construcción, su emplazamiento sobre plataformas, la asociación con plazas o kayanas y la presencia de nichos u otros rasgos que permitían la colocación de ofrendas y parafernalia ritual (Isbell 1997: 156).

Cabe destacar que ninguno de estos detalles nos remite necesariamente a la presunta función mortuoria de los edificios -a su interpretación como sepulcro- sino que revelan su importancia pública o se relacionan con las prácticas de veneración asociadas. Coincidimos con Isbell en la importancia que atribuye a los sepulcros abiertos como metonimias del antepasado, pero consideramos innecesario limitar la discusión a estas estructuras o a otras con función mortuoria, ya que excluye del argumento a otras expresiones monumentales del ancestro que desempeñaron un papel semejante en la práctica social. Ejemplos bien conocidos son las grandes rocas o monolitos (huancas), "hombres que fueron convertidos en piedra", según Arriaga (1968 [1621]: 24), considerados contrapartes pétreas de los malqui (Duviols 1979) o los propios cerros. Aunque albergar el cuerpo del difunto -o parte de él- fuera la principal vía por la que el antepasado animaba ciertas materialidades era sólo una de las formas posibles. Otras probablemente incluían las propias narraciones míticas referidas a ciertos objetos y lugares, relaciones de mímesis (mediante pinturas, máscaras) o alineamiento (orientación hacia cerros o pacarinas), ofrendas fundacionales, ritos dedicatorios, challas e invocaciones, como las que se realizan actualmente al iniciar ciertas ceremonias, cuando se convoca a los espíritus de los cerros y otras huacas por sus nombres.

Estas alternativas plantean desafíos a la inferencia arqueológica que sólo pueden ser resueltos mediante un análisis contextual "denso". Aquí sólo queremos enfatizar que la vinculación de distintos objetos, estructuras, lugares y actividades con la ancestralidad era fundamental para transponer la memoria del antepasado y las disposiciones asociadas fuera del contexto mortuorio a otros campos de la acción, incorporando así los antepasados y el orden por ellos fundado a la experiencia cotidiana de la comunidad. Desde este punto de vista, la polifuncionalidad de estas representaciones era tan importante como su monumentalidad (visibilidad y duración), punto sobre el que volveremos en la discusión.

Las grandes fiestas realizadas periódicamente en las plazas, donde se reunía la mayor parte de la comunidad, eran situaciones privilegiadas para el encuentro con los antepasados. Así lo sugiere la siguiente descripción:

"Se agrupan en la plaza por clanes y parcialidades y sacan los cuerpos momificados de sus ancestros, llamados munaos en las tierras bajas $y$ malquis en la sierra, junto con los cuerpos robados de la iglesia, y da la impresión de que los vivos y los muertos hubieran llegado al juicio. También sacan sus huacas personales, y los sacerdotes más destacados sacan las huacas que veneran en común. Se les preparan ofrendas y se exhiben las vestimentas que se utilizan en las fiestas y los plumajes con que se adornan, las vasijas, cántaros y vasos usados para hacer y tomar chicha que se ofrecen a las huacas, las trompetas, por lo general de cobre pero a veces de plata, y los grandes cuernos y otros instrumentos con los que convocan al festival" (Arriaga (1968 [1621]: 19).

Este pasaje revela cómo en las celebraciones públicas se ponía en juego, a través del ritual y las materialidades asociadas, la tensión entre fisión e integración propia de las formaciones descentralizadas. Por un lado, la segmentación de la sociedad se replica en la celebración a través de la presencia en la plaza de los fundadores de cada ayllu (malquis) y quizás de unidades sociales aún menores (las huacas personales). Esta fragmentación socio-ritual encuentra su contrapartida integradora, sin embargo, en las huacas veneradas por todos, asistidas por las autoridades principales de la comunidad. La identidad de cada grupo de descendencia se expresa también en la espacialidad de la ceremonia, agrupándose las personas en la plaza por "clanes". La misma práctica ha sido observada en las fiestas andinas actuales, en las que 
los miembros de cada ayllu ocupan posiciones discretas y claramente pautadas durante el transcurso de toda la celebración (G. Martínez 1989; Rasnake 1989). Esta "espacialidad segmentaria" se extiende al propio ámbito público y a su contenido (objetos, rasgos, estructuras, entre otros), como lo ejemplifica el trabajo etnográfico de G. Martínez (1989) en Isluga, donde cada mitad o ayllu es responsable del mantenimiento de ciertos calvarios, imágenes o sectores de la iglesia católica. Por último, la descripción muestra que la fiesta se estructuraba en torno a grupos y sus referentes sobrenaturales (huacas) antes que a la persona de los gobernantes u otros individuos, lo que resulta consistente con la naturaleza corporativa del orden social.

Como lo subrayamos anteriormente, sin embargo, los ancestros no actuaban sólo como referentes míticos de los poderes y autonomías corporativas, sino también de sus jerarquías. La transmisión de "agencia ancestral" a ciertos objetos, estructuras y geoformas definía entonces a la materialidad como una arena en la que se reproducían y renegociaban estas relaciones a través de un "diálogo silencioso" de posiciones, formas y sustancias con implicancias valorativas. La calidad de los atuendos que vestían los malquis, por ejemplo, dependía de su rango, reservándose los tejidos cumbi y ciertos colores o diseños exclusivamente para individuos de gran importancia. Lo mismo sucedía con las ofrendas y la vajilla empleada en "alimentarlos" durante las fiestas, en las que se empleaban metales para los principales, pero sólo arcilla para los más pobres (Guamán Poma 1980 [1615]: 231).

Varios testigos (p.e., Guamán Poma 1980 [1615]: 231; Arriaga 1968 [1621]) informan que durante las celebraciones públicas los malquis y otros ídolos se ubicaban en la plaza de acuerdo a su rango, lo que pone de relieve la capacidad del espacio para establecer diferencias de poder entre las personas. Las jerarquías espaciales obedecían a diferentes diseños (p.e., oposiciones arriba-abajo, secuencias de derecha a izquierda o centro-derechaizquierda: "triadismo lineal y concéntrico", respectivamente, según Pärssinen 1992). Estos modelos jerárquico-espaciales también se plasmarían en la forma y disposición de ciertos sepulcros y otras materialidades ancestrales, como lo sugiere el siguiente testimonio de una visita de idolatrías del siglo XVII, donde se describen los hallazgos realizados en la plaza de un antiguo poblado o llacta:

"Descubrieron un gran simulacro y templo de los tiempos paganos que tenía un pequeña plaza y muchos cuartos pequeños a su alrededor, y en el medio tres tumbas encerradas por muros de piedra, y abrieron y cavaron en la del medio y mostró el ídolo llamado Auca Atama, que era un cuerpo de un individuo pagano que los indios de este ayllu y los de Nanis adoraban, porque era su primer progenitor y conquistador y fundador del pueblo, y abrieron y cavaron las dos tumbas que estaban a ambos lados y mostraron cuatro ídolos malquis llamados Poron Tambo, Cunquis, Xulcas y Pariasca, quienes dijeron a través de los dichos intérpretes que eran hijos del dicho malqui, llamado Auca Atama, y a los costados de los dichos malquis, en unas pequeñas ventanas como capillas, mostraron cuatro ídolos conopa" (cit. en Isbell 1997: 91-92; la traducción es nuestra).

El consumo común de cantidades y calidades extraordinarias de comidas y bebidas era un aspecto central de las celebraciones públicas. Estas prácticas, acompañadas por danzas y cantares que conmemoraban las hazañas de los antepasados -en algunos casos específicamente de los guerreros preincas (Saignes 1993: 60) - y la propia embriaguez, permitían un contacto directo entre la comunidad y sus antepasados, al tiempo que diluía las fronteras entre el presente y el pasado mítico que dio origen al orden social.

Las fuentes etnohistóricas y etnográficas coinciden en que la organización de fiestas en honor a las huacas era una de las responsabilidades de las autoridades -que justificaba, en parte, la percepción del tributo- y que en ellas participaba la totalidad de la comunidad (Murra 1975; Rasnake 1989; Pease 1992). La "redistribución" de recursos y trabajo en las fiestas reproducía los aspectos jerárquicos, descentralizados e integrativos de las formaciones segmentarias. En primer lugar, porque la aceptación de la hospitalidad del curaca por los miembros de la comunidad implicaba (recíprocamente) una reafirmación de las obligaciones tributarias, a la vez que acrecentaba el prestigio (capital simbólico) de las autoridades. Segundo, la participación activa de todos o la mayoría de los grupos domésticos (sobre todo las mujeres) en la producción del evento y de los recursos que demandaba (ver p.e., Moore 1989) replicaba 
los aspectos descentralizados de la sociedad, permitiendo a las unidades sociales mínimas intervenir activamente en el ritual público que encarnaba el orden político, reconociendo allí los frutos de su trabajo. Tercero, las celebraciones públicas operaban como una fuerza integradora fundamental para contrarrestar la tendencia a la disgregación propia de las formaciones segmentarias (Isbell 1997: 95-97) no sólo por tornar la colectividad en una realidad tangible al congregar en un mismo espacio a los miembros de las distintas parcialidades o comunidades subordinadas a la misma estructura política, sino también por algunas de las connotaciones simbólicas de este tipo de prácticas. Dietler (2000: 69-70), por ejemplo, sostiene que el poder integrador del "comensalismo político" deriva de sus evidentes conexiones con la experiencia diaria de compartir alimentos en el ámbito doméstico. A través de esta evocación, estos ritos establecen un nexo práctico y experiencial entre lo público y lo doméstico, el ceremonial y la vida cotidiana, la comunidad y el individuo o su grupo familiar. En suma, la fiesta comunal permitía renovar la trama total de relaciones que daba forma a la sociedad (Dietler 2000: 73).

El comensalismo político cobra expresión arqueológica en una serie de espacios (áreas capaces de albergar a gran cantidad de personas), rasgos (estructuras para procesamiento de comidas en grandes cantidades o de dimensiones poco comunes o para la exhibición de los recursos a consumir), artefactos (tamaños y cantidades de vasijas) y desechos alimenticios de carácter excepcional (Hayden 2000: 40-41). Pero, como se indicó anteriormente, en las fiestas andinas los alimentos y el alcohol no sólo circulaban entre los vivos, sino que eran literalmente compartidos con los difuntos, lo que requería de dispositivos especiales, como los observados por Pedro Pizarro:

" $Y$ hacían fuegos frente a los difuntos con un pedazo de madera muy seca... Habiendo prendido fuego a este pedazo de madera, quemaban aquí todo lo que habían puesto delante del difunto para que pudiera comer las cosas que ellos comían, y aquí en este fuego las consumían. Asimismo, delante de estos difuntos tenían unas vasijas grandes, que llaman verquis, hechas de oro, plata o barro, cada uno de acuerdo a su deseo, y adentro vertían la chicha que le daban al hombre muerto con mucha ostentación... Cuando los verquis estaban llenos, los vaciaban en una piedra redonda en el medio de la plaza, y que decían que era un ídolo, y estaba hecha alrededor de una pequeña abertura por la que [la chicha] se escurría por unos caños que hacían bajo el suelo" (Pizarro 1571, cit. en Isbell 1997: 42-43).

Acciones semejantes y algunos de los objetos que involucraban (como p.e., vasijas de boca ancha o virques de acuerdo a la denominación actual) han sido también ilustradas por Guamán Poma (1980 [1615]: 263, 269) como lo ejemplifica el dibujo de un funeral en el Collasuyu reproducido en la Figura 1. Estos objetos permitirían en principio rastrear arqueológicamente algunas de estas acciones, como lo argumentaremos en la discusión.

Sintetizando, si las prácticas hasta aquí consideradas se encontraran ya vigentes entre los pueblos preincaicos de los Andes circumpuneños, esperaríamos encontrar en sus espacios públicos testimonios de:

1. Ceremonias focalizadas en representaciones de los antepasados como guardianes del orden corporativo.

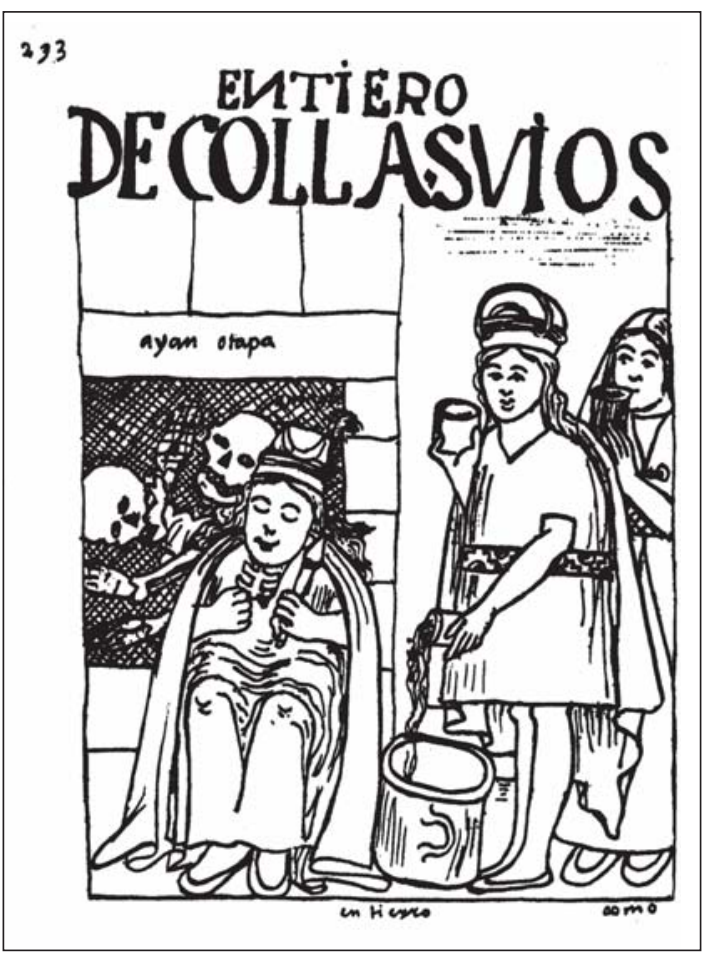

Figura 1. Entierro en el Kollasuyu según Guamán Poma de Ayala (1980 [1615]: 268). 
2. Referentes de identidades corporativas segmentadas (múltiples representaciones ancestrales) y jerarquizadas (mediante posiciones o formas) según la magnitud de las asimetrías existentes entre los grupos constitutivos.

3. Materialidades integradoras o abarcativas.

4. Consumo colectivo de comidas y bebidas de carácter excepcional.

\section{El sector central de Los Amarillos}

Los Amarillos es uno de los asentamientos conglomerados de mayores dimensiones que se conocen para la quebrada de Humahuaca (Figura 2).
El sitio comienza a ser ocupado alrededor del 1000 DC, alcanza su máxima extensión ( $c a .10$ ha densamente edificadas) durante los siglos XIV y XV, al momento de la expansión incaica, es abandonado en su mayor parte, aunque una parte del sector central continúa siendo habitada, posiblemente hasta los primeros momentos de la Colonia (Nielsen 2006). Esta trayectoria hace razonable suponer que, a diferencia de lo que sucede en otros conglomerados de la región que alcanzaron su clímax en la era del Tawantinsuyu, los rasgos fundamentales de la estructura interna de Los Amarillos corresponden a la organización del poblado antes de la conquista incaica. Entre estos rasgos, nos interesa destacar la presencia de una jerarquía de espacios públicos, con un sector central

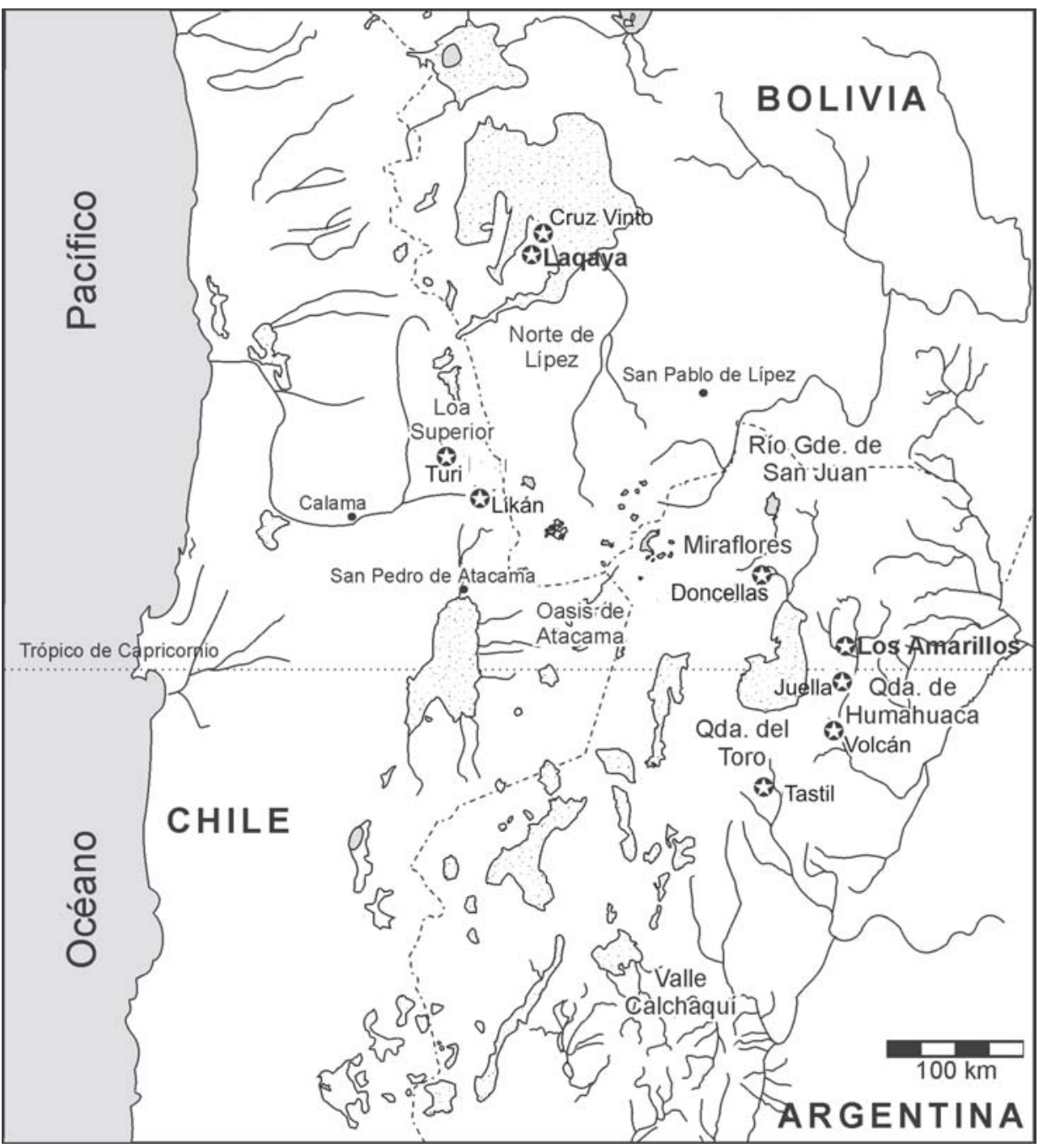

Figura 2. Ubicación de algunos sitios y regiones mencionados en el texto. 


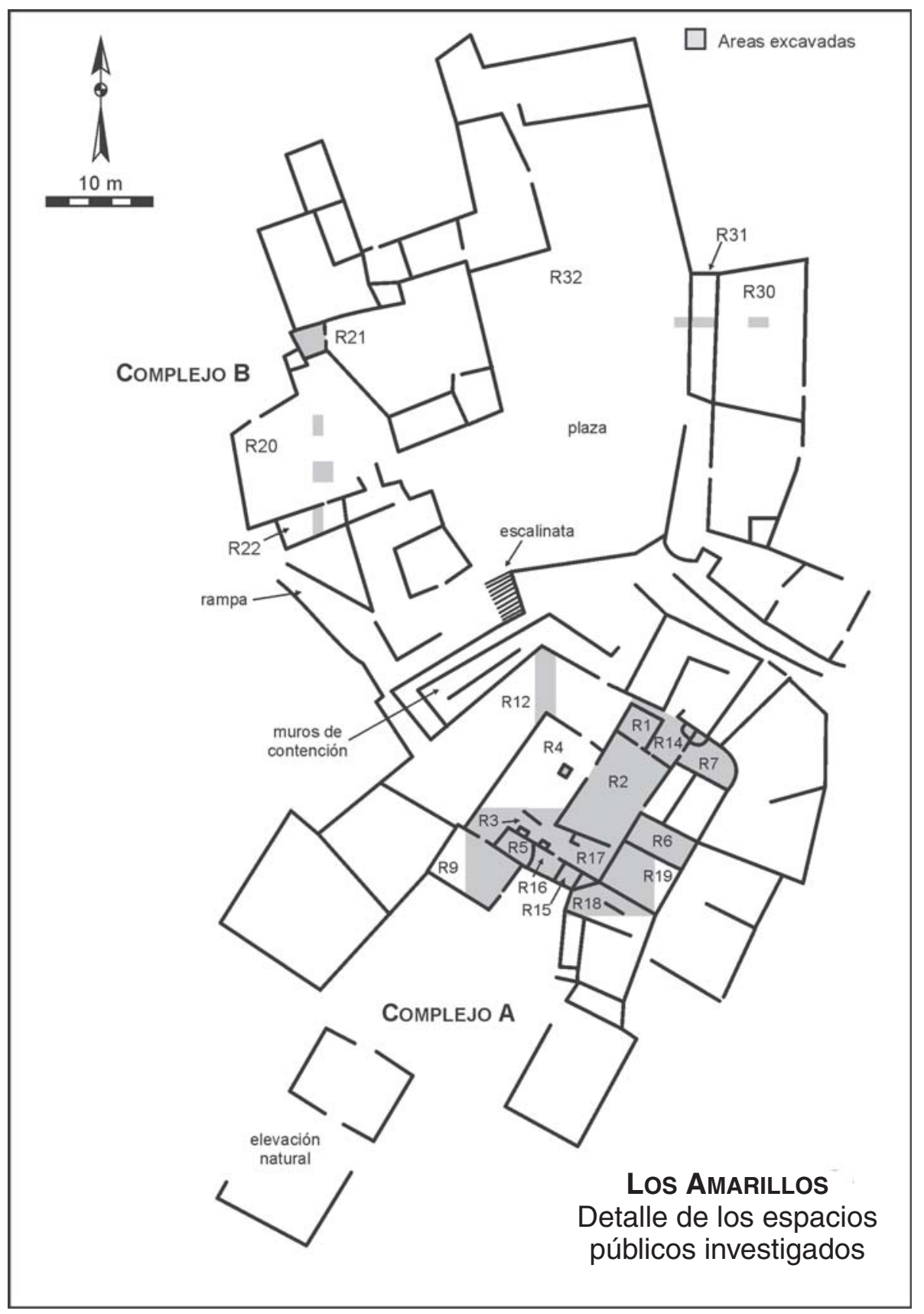

Figura 3. Planimetría del Sector Central de Los Amarillos indicando los sectores excavados.

dotado de varias plazas donde convergen las principales vías de circulación del sitio, y espacios públicos simples distribuidos en los distintos sectores edificados. En otra oportunidad denominamos a esta estructura "polinuclear compleja" (Nielsen 1996a).
Nuestras excavaciones se concentraron en lo que denominamos Complejo $\mathrm{A}^{7}$, una plataforma arti-

\footnotetext{
7 Utilizamos flexiblemente el concepto de "complejo" arquitectónico para aludir a un conjunto de locales, espacios y estructuras que desde la observación superficial parecen relacionarse funcionalmente a juzgar por sus vínculos de contigüidad y acceso.
} 
ficial construida contra un afloramiento natural de arenisca en el extremo sur de la principal plaza del sector central, y secundariamente en el Complejo B, un conjunto de estructuras que -desde el punto de vista de la circulación- se interponen entre la plataforma y la plaza (Figura 3). La plaza misma (Recinto 32), situada entre 4 y $6 \mathrm{~m}$ por debajo del nivel del Complejo A, fue objeto de un sondeo que puso al descubierto una superficie bien consolidada, aparentemente bien mantenida a juzgar por la escasez de desechos asociados, entre los que sólo merecen destacarse dos cuentas de bivalvos marinos (Semele o Mesodesma). Cabe notar que, a pesar de su contigüidad, esta estructura y el Complejo A tienen accesos separados y no están comunicados directamente, sino sólo a través del Complejo B. Sobre el talud que bordea la plataforma, hay por lo menos una escalinata con diminutos peldaños; antes que un acceso funcional, este rasgo se presenta como un dispositivo escenográfico que, junto con los muros de contención escalonados, destacan visualmente la plataforma desde la perspectiva del observador ubicado más abajo, en la plaza (Nielsen 1995). Identificamos tres componentes estratigráficos principales que son particularmente claros en el Complejo A:

1. El primero consiste en una serie de superficies de ocupación previa a la construcción de la plataforma, correspondiente al Período de Desarrollos Regionales Temprano (900-1250 DC).

2. A fines del siglo XIII se construye la plataforma mediante la acumulación rápida de un relleno artificial (cascajo y basura) sostenido con muros de contención. Sobre ella se erigieron varios edificios (Figura 4). Estas estructuras, que fueron utilizadas durante el Período de Desarrollos Regionales Tardío (1250-1430 DC), mantienen una evidente relación con la plaza, lo que nos permite tratarlas como parte del "espacio público". Al final de este período, todo el Complejo A y al menos parte del $\mathrm{B}$ fueron quemados y destruidos.

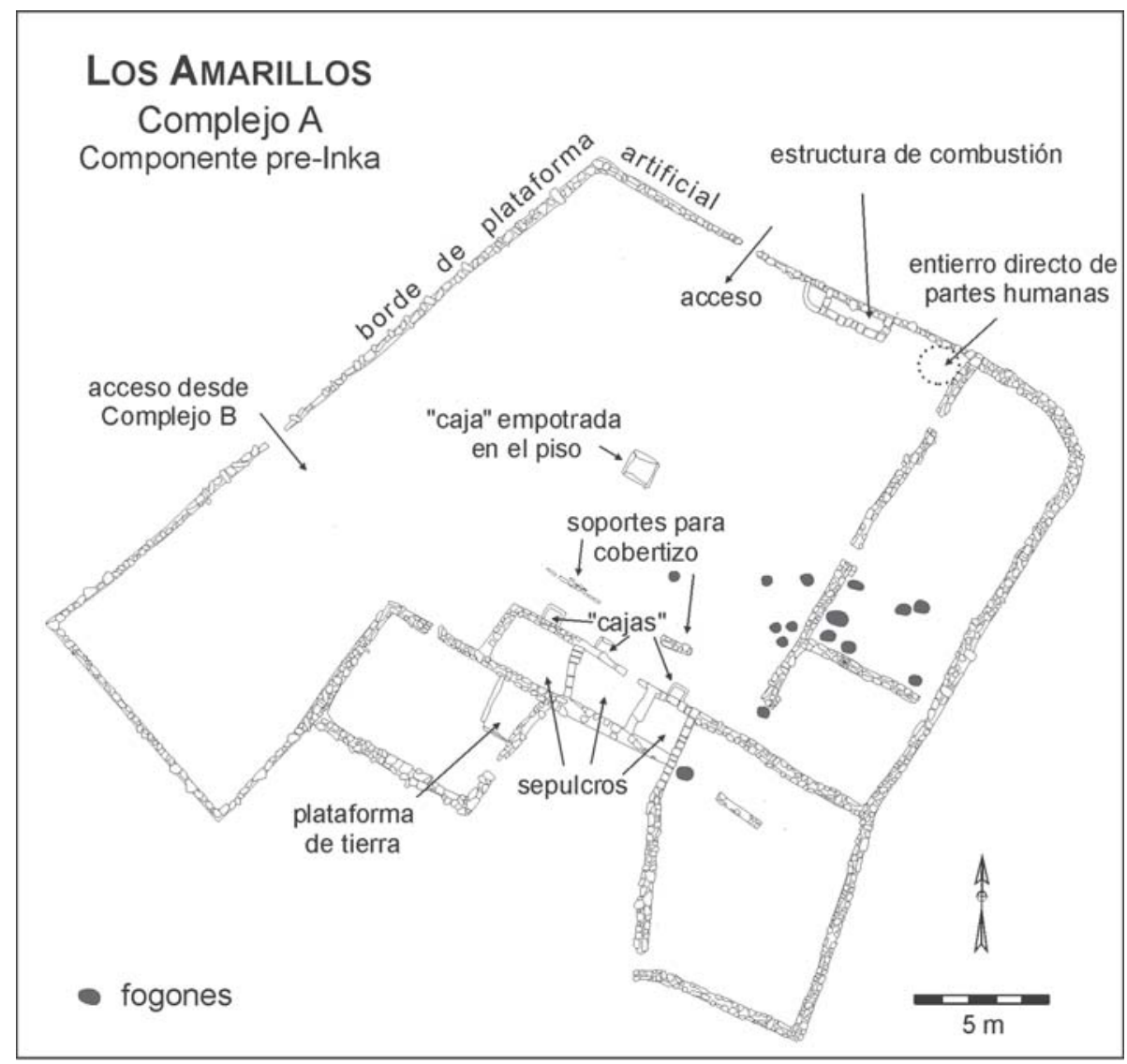

Figura 4. Planimetría de la plataforma del Complejo A, de alrededor del siglo XIV, de Los Amarillos. 


\begin{tabular}{|lllll|}
\hline Procedencia & Código & C $^{\mathbf{1 4}}$ AP & Cal AD 2 $\sigma$ & Evento asociado - Observaciones \\
\hline Los Amarillos R 12 & LP-659 & $920 \pm 50$ & $1030-1270$ & Ocupación previa a plataforma \\
Los Amarillos R 16 & AA-16239 & $620 \pm 49$ & $1290-1440$ & Contenido sepulcros sobreelevados \\
Los Amarillos R 1B & AA-12135 & $590 \pm 55$ & $1300-1450$ & Uso de la plataforma previo al Inca \\
Los Amarillos R 14 & A-9600 & $505 \pm 50$ & $1390-1620$ & Incendio del Complejo A \\
Los Amarillos R 1 & AA-12136 & $450 \pm 50$ & $1410-1630$ & Incendio del Complejo A \\
Laqaya R 300 & A-10945 & $600 \pm 90$ & $1270-1500$ & Uso recintos asociados a la plaza \\
Laqaya R 300 & A-10944 & $575 \pm 55$ & $1300-1460$ & Uso recintos asociados a la plaza \\
\hline
\end{tabular}

Tabla 1. Fechas radiocarbónicas asociadas a las plazas investigadas. ${ }^{8}$

3. Sobre las ruinas del Complejo A se levantaron, inmediatamente después, nuevas estructuras de uso doméstico cuyos desechos incluyen una considerable cantidad de artefactos de filiación incaica. Estas estructuras se distribuyen en torno a un patio interno, dando la "espalda" a la plaza, lo que nos lleva a concluir que durante esta época la plataforma perdió su carácter público.

En este trabajo centraremos la atención en el segundo componente (PDRII), correspondiente al uso público para el que fue originalmente construida la plataforma, que de acuerdo a los datos radiocarbónicos calibrados datan del siglo XIV y principios del XV (Tabla 1). Para esta época, reconocemos la existencia de un mínimo de tres sectores diferenciados en la plataforma, división que debe ser tomada con cautela, teniendo en cuenta que sólo se excavó un 30 ó $40 \%$ de la misma. El primero está formado por una gran superficie nivelada de poco más de $300 \mathrm{~m}^{2}$ abierta a modo de "escenario" hacia la plaza. Aunque había muy pocos desechos en este sector, se encontraron, además de algunos fogones en cubeta hacia el ángulo sureste, tres rasgos singulares que merecen ser destacados: 1) un pozo poco profundo donde habían sido inhumados huesos (exclusivamente partes de torsos y extremidades superiores) correspondientes a dos individuos adultos muy incompletos (uno de ellos una mujer); 2) una gran estructura de combustión de planta rectangular $(2 \times 0.8 \times 0.4 \mathrm{~m})$, limitada en partes con muros de tierra y algunos ladrillos de arcilla gris (¿refractario?), rellena con una espesa capa de ceniza, y 3) una "caja" cuadrada con sus lados revestidos en piedra, situada hacia el centro geométrico del escenario, sin desechos ni otros rastros visibles en su interior, pero con restos de una gran fuente a su lado.
El segundo sector comprende un recinto rectangular (Recinto 9) y tres sepulcros de planta cuadrangular-irregular (Recintos 5, 15 y 16) erigidos sobre la plataforma que parecen haber estado protegidos hacia el norte por una especie de cobertizo (Recintos 3 y 17) a juzgar por la presencia de lo que parecen bases de columnas (de madera o tierra) confeccionadas en piedra. El Recinto 9, que estuvo originalmente techado, contenía muy pocos artefactos, desechos o rasgos que permitieran establecer su funcionalidad, fuera de un poyo o plataforma rectangular de tierra construida en una esquina.

De los sepulcros sólo se conservan las bases de los muros, ya que fueron parcialmente demolidos tras el incendio del Complejo, como lo atestigua el hallazgo de partes de los muros de fachada caídos directamente sobre el piso del cobertizo frente a ellos. Mientras que su pared sur es doble, de piedra con mortero de barro (como la mayor parte de la arquitectura del sitio), los demás muros han sido confeccionados con ladrillos de adobe asentados sobre cimientos de piedra. Las tres estructuras varían en tamaño y en la forma de su planta; sólo el central cuenta con una puerta reconocible, los otros debieron tener alguna abertura situada más arriba en el muro. En su interior había restos de torta, madera de cardón y paja quemada que pudieron ser partes del techo. Estos sepulcros sobreelevados son los únicos conocidos para la quebrada, donde la práctica habitual es el entierro directo o en cistas dentro del espacio doméstico.

8 Calibraciones realizadas con el programa OxCal 3.10 (Bronk Ramsey 2005), utilizando datos atmosféricos para el hemisferio sur de McCormac y colaboradores (2004), redondeadas por década. 
En el área ocupada por el posible "cobertizo", adosados a la fachada de cada sepulcro había tres rasgos con forma de "cajas"; la del centro (frente al Recinto 16) estaba formada por dos lajas dispuesta verticalmente y se encontró rellena con cenizas, aunque sin rastros de combustión in situ; las otras dos, completamente vacías, estaban formadas por un muro bajo de tierra en forma de 'U'. Aquí encontramos también un artefacto semejante a un mortero profundo confeccionado en roca caliza, con un orificio en su base. Estaba apoyado sobre el piso, boca abajo.

El contenido de los tres sepulcros era similar y evidentemente fue depositado (o redepositado) en un mismo evento. Consistía en una capa de unos $40 \mathrm{~cm}$ de espesor conteniendo abundante carbón y numerosos objetos fragmentados, muchos de ellos parcialmente quemados. Se establecieron múltiples remontajes entre los objetos recuperados en los tres sepulcros y en el cobertizo frente a ellos, pudiendo reconstruir tanto vasijas cerámicas, como artefactos de hueso y madera (Figura 5a); en varios casos los remontajes unen fragmentos quemados y sin quemar del mismo objeto. A partir de los indicios presentados hasta aquí, podemos reconstruir los siguientes pasos en la formación de los depósitos de este sector: a) se extrajo el contenido de los sepulcros (restos humanos y objetos de acompañamiento); b) se colocó un sahumador en el piso de cada sepulcro y un tumi de bronce en el umbral del Recinto 9; c) los materiales extraídos fueron fragmentados y luego d) quemados, un incendio que comprometió a toda o la mayor parte de la plataforma; e) se demolieron los sepulcros, cayendo partes de sus muros de adobe sobre el material aún incandescente; f) se volvió a depositar el contenido (antes de concluir su combustión) dentro de lo que quedó en pie de las estructuras, terminando partes de los mismos objetos depositados en distintos lugares o abandonados en el área del cobertizo. Poco des-

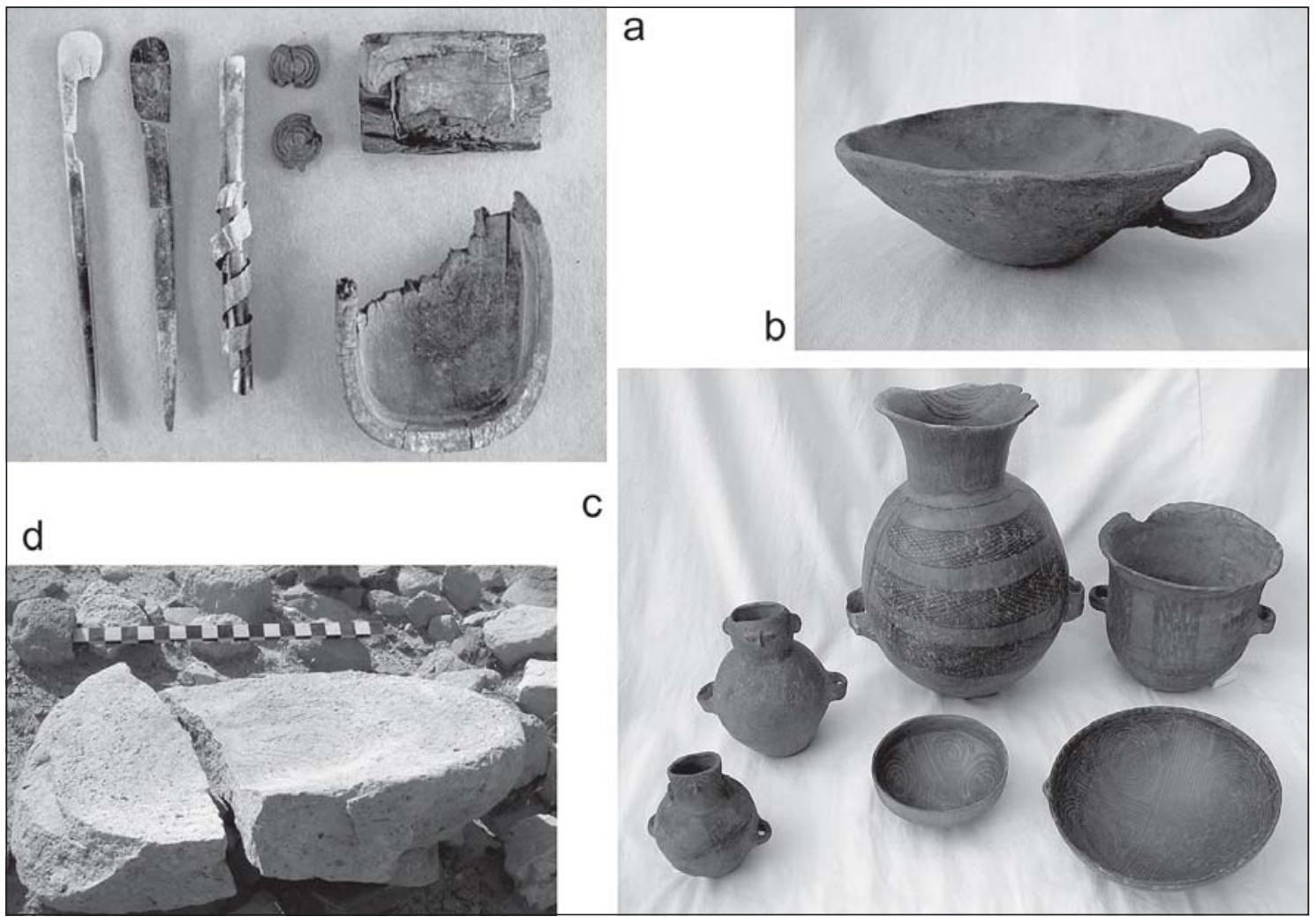

Figura 5. a) Algunos objetos vinculados a la inhalación de alucinógenos recuperados en los sepulcros; b) Una de las escudillas con asa lateral o sahumadores con residuos carbonizados en su interior recuperadas en los sepulcros sobreelevados del Complejo A; c) Ejemplos de vasijas con formas y diseños pintados característicos del Período de Desarrollos Regionales Tardío en la Quebrada de Humahuaca. De izquierda a derecha; adelante: escudilla y fuente; atrás: dos yuros antropomorfos, un cántaro y una vasija de boca ancha o virque. d) Uno de los grandes molinos visibles en las inmediaciones del Complejo A. 
pués se edificaron las estructuras domésticas sobre el "escenario", cubriendo las ruinas de los sepulcros con un basurero (Nielsen y Walker 1999).

La Tabla 2 detalla los elementos recuperados dentro de los sepulcros, que probablemente sólo representen una fracción de su contenido original, ya que es evidente que algunos ítemes fueron definitivamente extraídos durante la destrucción o redepositados en otras áreas. Estos datos muestran, en primer lugar, una correspondencia entre la presencia de tres sepulcros y tres individuos adultos; el perinato pudo ingresar junto con el cuerpo de la mujer. Las inclusiones funerarias comprenden objetos habitualmente interpretados como "bienes de prestigio" en la literatura regional (p.e., equipos de inhalar alucinógenos [Figura $5 \mathrm{a}]$, collares de cuentas de concha y minerales de cobre o vestimentas ornamentadas con cuentas y

\begin{tabular}{|c|c|c|c|}
\hline Huesos humanos & \multicolumn{3}{|c|}{$\begin{array}{l}352 \text { fragmentos }(88 \% \text { quemados }) \\
\text { MNI }=4 \text { ( } 1 \text { adulto femenino, } 2 \text { adultos masculinos, } 1 \text { perinato })\end{array}$} \\
\hline Madera & \multicolumn{3}{|c|}{$\begin{array}{l}2 \text { tabletas de inhalar, una subcircular (sebil) y fragmentos de una subrectangular } \\
2 \text { tubos de inhalar (mínimo), uno con talla zoomorfa (sebil) y otro en fragmentos } \\
2 \text { estuches (mínimo), uno prismático (cedro) y uno cilíndrico } \\
2 \text { fragmentos de mangos de cucharas (?) grabados (quebracho blanco) } \\
1 \text { tortero circular (queñoa) } \\
1 \text { objeto alargado pulido: ¿huso? (aromo) } \\
2 \text { agujas de espina de cardón } \\
\text { maderas planas trabajadas (cardón, churqui y otras) } \\
\text { fragmentos de astiles (churqui, aromo y otros) }\end{array}$} \\
\hline Artefactos de hueso & \multicolumn{3}{|c|}{$\begin{array}{l}1 \text { tubo de inhalar (hueso largo de flamenco) } \\
1 \text { machacador plano } \\
1 \text { boquilla de trompeta decorada }\end{array}$} \\
\hline Metal & \multicolumn{3}{|c|}{$\begin{array}{l}1 \text { espiral de oro (probablemente revestía un tubo inhalador) } \\
2 \text { láminas rectangulares de aleación oro-plata, originalmente cosidas a tejidos } \\
3 \text { fragmentos de objetos de cobre no identificados }\end{array}$} \\
\hline Cuentas & \multicolumn{3}{|c|}{$\begin{array}{l}3 \text { cuentas en placa de gualacate (Euphractus sexcinctus) } \\
3980 \text { cuentas de concha (los ejemplares identificados corresponden a bivalvos marinos: Pectinidae y } \\
\text { Semele o Mesodesma) } \\
3840 \text { cuentas de minerales de cobre } \\
2 \text { cuentas de alabastro } \\
2 \text { cuentas decoradas de hueso }\end{array}$} \\
\hline Lítico & \multicolumn{3}{|c|}{$\begin{array}{l}13 \text { puntas de proyectil ( } 10 \text { de sílice gris, } 3 \text { de obsidiana) } \\
1 \text { tortero circular de piedra pulida } \\
1 \text { placa con residuos de pigmento rojo y resina } \\
1 \text { sobador } \\
\text { desechos de talla en obsidiana (34, fuente Laguna Blanca) y sílice gris (12) }\end{array}$} \\
\hline Cerámica & \multicolumn{3}{|c|}{813 fragmentos (ver detalle en Tabla 3 ) } \\
\hline Restos óseos animales & $\begin{array}{l}\text { NR: }(52 \% \text { q } \\
\text { Taxón } \\
\text { Camelidae } \\
\text { Artiodactyla } \\
\text { Avis } \\
\text { Cervidae } \\
\text { Euphractus } \\
\text { Canidae } \\
\text { Total NISP }\end{array}$ & $\begin{array}{l}\text { dos) } \\
\text { NISP } \\
160 \\
182 \\
72 \\
1 \\
52 \\
2 \\
469\end{array}$ & $\begin{array}{l}\text { MNI } \\
3 \text { (una vicuña) } \\
- \text { (probablemente corresponden a camélido) } \\
2 \text { (un Pcitacidae) } \\
1 \\
1 \text { (placas de caparazón de quirquincho exclusivamente) } \\
1 \\
-\end{array}$ \\
\hline Restos macrobotánicos & \multicolumn{3}{|c|}{$\begin{array}{l}\text { Maíz ( } 1 \text { fragmento de marlo quemado y granos), ají ( } 1 \text { fruto), maní ( } 3 \text { fragmentos de cáscara), achira } \\
\text { ( } 1 \text { semilla), chañar ( } 2 \text { carozos), calabaza ( } 6 \text { fragmentos), Cucurbita ficifolia o "cayote" ( } 58 \text { semillas y } \\
\text { fragmentos), cortadera (tallos) }\end{array}$} \\
\hline Otros & \multicolumn{3}{|c|}{ Cestería, cordeles, fragmentos de textiles quemados (prendas y una bolsa) } \\
\hline
\end{tabular}

Tabla 2. Materiales recuperados dentro de los sepulcros sobreelevados del Complejo A de Los Amarillos (Recintos 5, 15 y 16). 


\begin{tabular}{|c|c|c|c|c|}
\hline Clases de vasijas & $\begin{array}{c}\text { Sepulcros } \\
(\mathbf{R} 5,15 \text { y 16) }\end{array}$ & $\begin{array}{c}\text { Cobertizo }^{\mathrm{a}} \\
(\mathrm{R} 3 \text { y 17) }\end{array}$ & Recinto $9^{b}$ & $\begin{array}{c}\text { Sector oriental } \\
\text { (R6, } 18 \text { y 19) }\end{array}$ \\
\hline Olla & 5 & 2 & 1 & 4 \\
\hline Cántaro-yuro & 11 & 5 & 9 & 29 \\
\hline Fuente & 6 & 3 & 1 & 9 \\
\hline Escudilla & 7 & 4 & 6 & 1 \\
\hline Sahumador & 5 & 2 & - & - \\
\hline Vasija boca ancha & - & - & - & 1 \\
\hline Vaso de hilar & 1 & - & - & - \\
\hline
\end{tabular}

Tabla 3. Artefactos cerámicos (MNI) recuperados en distintos sectores del Complejo A de Los Amarillos (componente PDRII). ${ }^{a}$ Varios remontajes con tiestos al interior de los sepulcros; ${ }^{b}$ en su mayoría tiestos aislados.

chapas de oro), junto con otros cuyo valor es más difícil establecer (p.e., herramientas para hilar, trompeta, flechas, sahumadores [Figura 5b]), y una variedad de restos de plantas y animales (un cráneo completo de vicuña, el esqueleto de un loro). Muchos de estos elementos son, además, alóctonos procedentes de las yungas, puna y Pacífico, como por ejemplo, maderas (sebil, quebracho, cedro), semillas (achira, nogal) y fauna (loro, gualacate, vicuña, flamenco), metales (oro) y rocas (obsidiana, sílices).

Del tercer sector del Complejo A, que denominamos "oriental", sólo se excavaron el Recinto 6 en forma total y los Recintos 18 y 19 en forma parcial. En el Recinto 6 se identificaron unos siete fogones escasamente formatizados. Sobre el piso había desechos (cerámica, huesos de animales) en un nivel de carbón y cenizas que continuaba en el Recinto 19. El Recinto 18 tenía un fogón y abundantes residuos de facto sobre el piso, incluyendo maíz quemado, fragmentos de textiles muy deteriorados (talvez bolsas conteniendo originalmente los granos) y varias vasijas pintadas en negro y rojo aplastadas por el derrumbe del techo. Entre ellas había varios cántaros de gran tamaño (>100 lt), cántaros pequeños (yuros) y fuentes con asas de hasta $50 \mathrm{~cm}$ de diámetro (los especímenes más grandes de esta forma que conocemos para la región) comparables a la ilustrada en la Figura 5c. Como lo demuestra la Tabla 3, hay considerables diferencias entre la cerámica recuperada aquí y la obtenida dentro y alrededor de los sepulcros, lo que pone de relieve las diferencias funcionales entre ambos sectores.

Las excavaciones en el Complejo B son aún muy limitadas para poder avanzar interpretaciones sobre las actividades allí desarrolladas, aunque todo indica una estrecha vinculación con el Complejo
A, con el que se comunica directamente mediante una rampa. Uno de los recintos allí excavados $\left(n^{\circ} 21\right)$, por ejemplo, tenía como único rasgo un pequeño pozo -que se encontraba abierto al momento del abandono de la habitación- conteniendo algunos huesos humanos correspondientes a una mujer adulta y un neonato; también había sido quemado y los desechos recuperados entre las cenizas sobre el piso incluían una lámina de oro con orificios para sujetarla a un tejido, dos cascabeles de nuez, una cuenta de hueso decorada idéntica a las encontradas en uno de los sepulcros sobreelevados y fragmentos de un tubo de inhalar semiquemado con decoraciones grabadas.

No quisiera concluir la presentación de este primer caso sin mencionar que en y alrededor del Complejo A se ven grandes molinos confeccionados en granito o en caliza (como el ejemplar de la Figura 5d). Aunque los implementos de molienda son muy frecuentes en las áreas domésticas del sitio, artefactos de este tamaño no han sido hasta ahora observados -ni en superficie ni en excavación- fuera del ámbito público.

\section{La Plaza Central de Bajo Laqaya}

Laqaya es uno de los asentamientos de mayor tamaño que conocemos en el Norte de Lípez. Consta de tres sectores: un pucara con casi 100 recintos protegido por dos murallas en la cima de un promontorio ("Alto Laqaya"), un área con más de 300 torres de piedra tipo chullpa distribuidas al pie de la elevación y un poblado sin defensas formado por algo más de 200 viviendas simples (ver planimetría en Nielsen 2002: 190). Hasta donde sabemos, la ocupación se inició en el poblado sin defensas ("Bajo Laqaya") alrededor de 1200 DC, o quizás antes. A fines del siglo XIII, coincidiendo con la aparición de la cerámica pintada del 


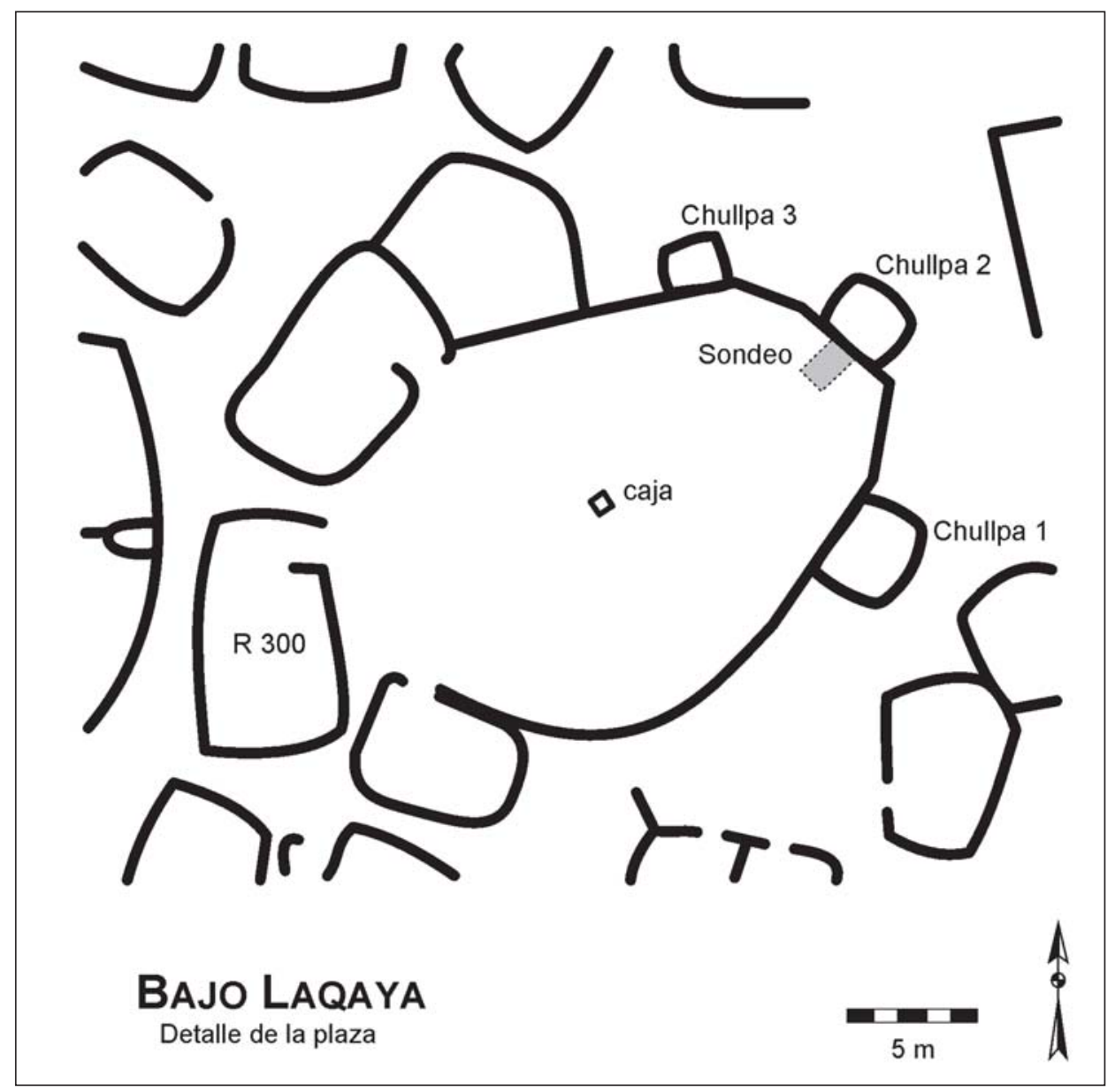

Figura 6. Detalle de la planimetría de Bajo Laqaya mostrando la plaza central y las estructuras excavadas.

grupo Mallku/Hedionda -el estilo cerámico considerado emblemático de los Desarrollos Regionales en Lípez (Arellano y Berberián 1981)- este poblado se expande, se construye el pucara y comienzan a erigirse las torres del "sector chullpas". A pesar de haberse encontrado algunos tiestos incas aislados en la superficie del "Alto Laqaya", los materiales de excavación y las fechas radiocarbónicas asociadas indican que el pucara no fue habitado luego del siglo XV. Durante el Período Inca y los comienzos del Hispano-indígena (hasta el siglo XVII por lo menos), la ocupación continuó en el poblado bajo, aunque probablemente sólo en su porción norte.

En Bajo Laqaya se advierten dos plazas, pero sospechamos que la más pequeña, ubicada hacia el norte del poblado, corresponde exclusivamente a la época Hispano-indígena o Inca a lo sumo.
Las investigaciones que nos interesan discutir aquí fueron realizadas en el espacio público principal, un área nivelada y despejada de contorno irregular, de unos $280 \mathrm{~m}^{2}$, ubicada cerca del centro del sitio y enmarcada por una densa red de edificación (Figura 6). Sobre el flanco oriental de este espacio se levantan tres torres chullpa $a^{9}$ de planta rectangular confeccionadas en piedra, mientras que sobre el lado occidental se encuentran tres grandes recintos que originalmente estuvieron techados a dos aguas. Uno de ellos (Recinto 300) fue excavado en su totalidad. En el costado norte, adosado a uno de estos recintos se ve otra estructura, de planta irregular, cuya función por ahora

\footnotetext{
Empleamos esta categoría para referirnos a la forma arquitectónica prescindiendo por ahora de supuestos sobre los usos a que estuvo sujeta.
} 
desconocemos, pero que no parece haber estado techada. Al centro de la plaza hay un rasgo que probablemente fue una "caja" o pozo revestido en piedra, pero cuya forma no pudimos determinar con certeza ya que se encontraba perturbado.

Un sondeo de 2 x 1 m excavado en la plaza frente a la Chullpa 2 puso al descubierto tres niveles estratigráficos diferenciados correspondientes a otros tantos componentes presentes en el espacio público:

1. El primero, carente de alfarería pintada, corresponde a un depósito de basura previo a la construcción de la chullpa y del muro perimetral de la plaza y, por lo tanto, anterior a la creación del espacio público.

2. El segundo componente, que se iniciaría con la construcción de la chullpa y la propia plaza, comprende desechos acumulados durante el uso del espacio público e incluye alfarería Mallku/Hedionda. Dos fechas radiocarbónicas obtenidas sobre muestras procedentes del piso del Recinto 300 permitirían situar este componente en el siglo XIV y primera mitad del XV, en absoluta contemporaneidad con el uso público del Complejo A de Los Amarillos.

3. El tercer componente resultaría de depositaciones posteriores al abandono de la plaza, como lo indica la inclusión de piedras del derrumbe de la chullpa. Esta capa podría ser relacionada al relleno del Recinto 300, formado por una densa acumulación de basura que revela la continuidad de ocupación del sitio aún después del abandono de la plaza y las estructuras asociadas. La presencia de escasos fragmentos de filiación inca en el relleno del Recinto 300 y de la Chullpa 2 ubicarían la formación de este componente en la época del Tawantinsuyu, continuándose quizás durante el período posterior a la conquista europea.

Las chullpas sólo se conservan a nivel de cimiento $(50 \mathrm{~cm}$ es la altura máxima de los muros actualmente conservados), ya que este sector del sitio fue sistemáticamente minado hace algunas década para usar sus piedras en la construcción de caminos. Los vecinos de mayor edad, sin embargo, recuerdan que antes del desmantelamiento, estos edificios eran "más altos que una casa". Los muros remanentes son anchos y están cuidadosamente confeccionados con doble hilera de piedras asentadas con cascajo pequeño y uniones rellenas con barro. Las tres estructuras fueron investigadas. De la mayor (Chullpa 1) se excavó un cuarto, de la más pequeña (Chullpa 3 ) la mitad, mientras que la mediana (Chullpa 2) se excavó en su totalidad (Figura 7).

Las excavaciones mostraron que las tres torres poseen un piso interior de piedras planas ajustadas con barro. En el caso de la Chullpa 1, se constató que existían por lo menos dos emplantillados superpuestos, quizás testigos de un acto de renovación de la estructura. ${ }^{10}$ En los tres casos había una capa superior formada por relleno eólico posterior al abandono, que incluía piedras procedentes del derrumbe de los muros y algo de basura. En la Chullpa 1, esta capa se asentaba directamente sobre el piso, indicando que la estructura estaba vacía o fue vaciada al momento del abandono. En la Chullpa 3, en cambio, se interponía un espeso nivel de cenizas mezcladas con desechos (cerámica, debitage, huesos de animales) y trozos de barro quemado, probablemente correspondientes a la combustión del techo. Esta secuencia se repetía con mayor claridad en la Chullpa 2, donde los restos del techo incinerado incluían fragmentos de tirantes de madera de cardón, paja y trozos de barro semicalcinado. Entre este nivel y el piso había cerámica fragmentada (alisada, Mallku), instrumentos y desechos líticos (principalmente azadas de andesita o chelas y lascas de reactivación), así como trozos de bolsas tejidas y gran cantidad de granos de quinoa quemados. Evidentemente, estos materiales estaban dentro de la chullpa cuando se incendió el techo. No había huesos humanos.

El Recinto 300 posee una planta ligeramente trapezoidal, de unos $10 \times 5 \mathrm{~m}$ aproximadamente (Figura 8). En su interior había gran cantidad de basura, tanto en el relleno como en el piso, sin que existieran diferencias apreciables en los materiales contenidos en estos dos depósitos (Tabla 4). La alfarería recuperada -que en el caso del piso podrían relacionarse con las actividades realizadas dentro del edificio- incluye, además de una mayoría de material alisado, una reducida propor-

10 Los emplantillados no fueron desmantelados, ya que permanecieron expuestos para ser vistos desde el sendero interpretativo que actualmente permite a los turistas recorrer las ruinas. 


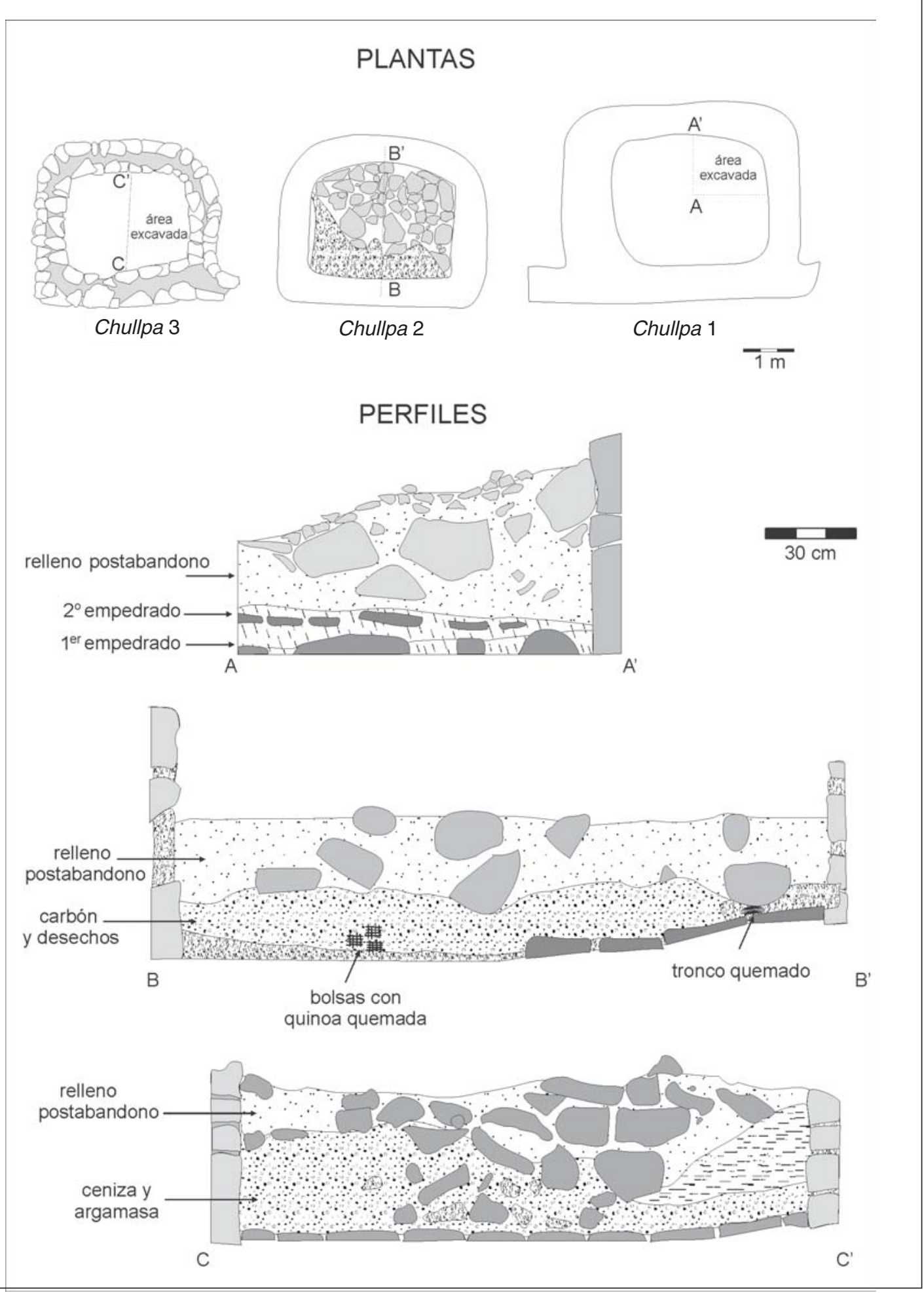

Figura 7. Detalles de las tres chullpas que flanquean la plaza central. 


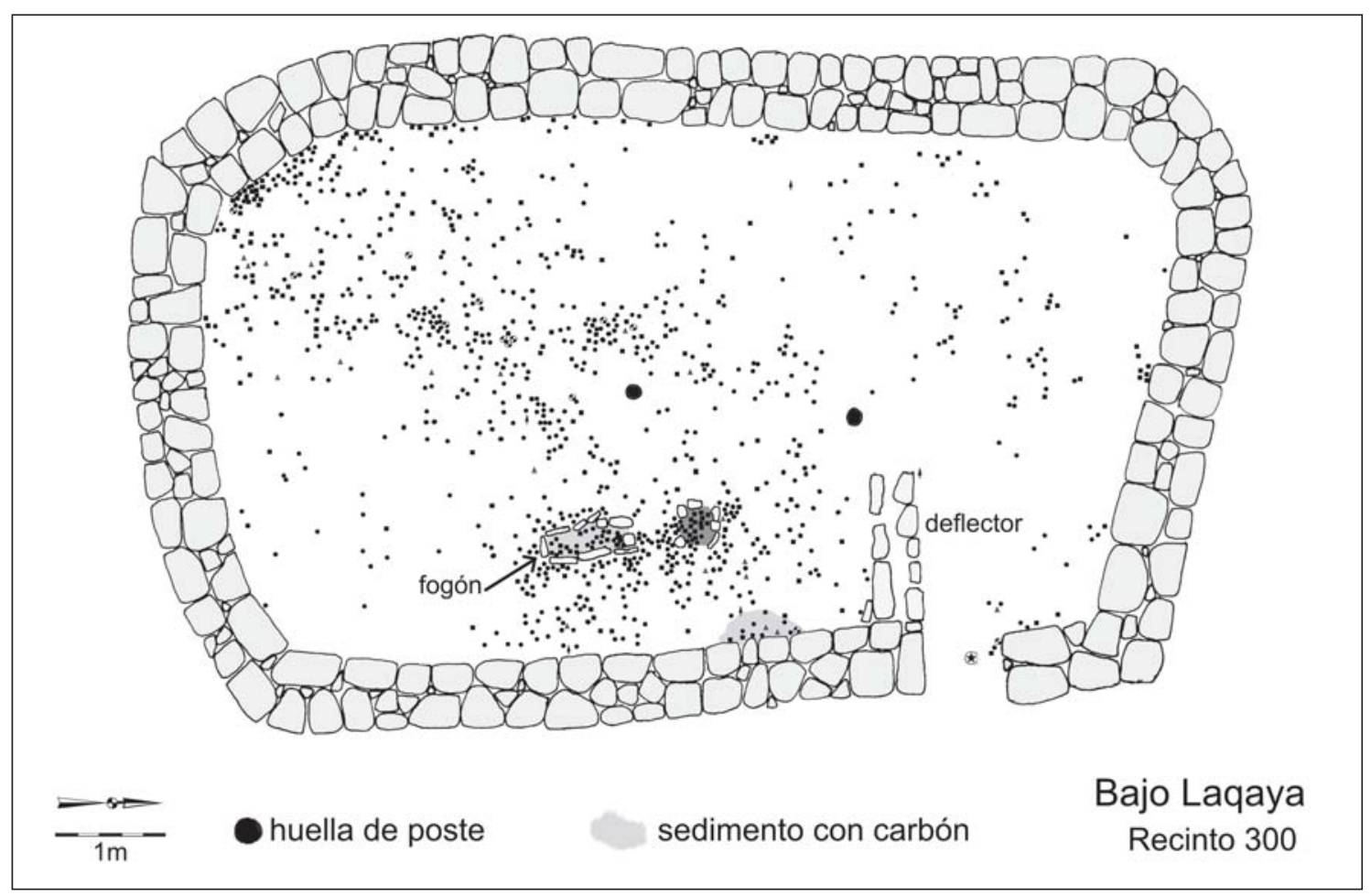

Figura 8. Planta del Recinto 300 mostrando los rasgos y la distribución general de desechos en el piso.

\begin{tabular}{|c|c|c|c|c|}
\hline \multicolumn{3}{|c|}{ Tipo de ítem } & Piso & Relleno \\
\hline \multirow[t]{3}{*}{$\begin{array}{l}\text { Cerámica } \\
\text { (total fragmentos) }\end{array}$} & Grupos & $\begin{array}{l}\text { Alisado } \\
\text { Mallku } \\
\text { Talapaca } \\
\text { Otros } \\
\text { Total }\end{array}$ & $\begin{array}{c}3815 \\
159 \\
66 \\
20 \\
4060\end{array}$ & $\begin{array}{c}22000 \\
833 \\
811 \\
93 \\
23737\end{array}$ \\
\hline & MNI & $\begin{array}{l}\text { escudillas } \\
\text { contenedores }\end{array}$ & $\begin{array}{l}96(53.6 \%) \\
83(46.4 \%)\end{array}$ & $\begin{array}{l}534(55 \%) \\
436(45 \%)\end{array}$ \\
\hline & \multicolumn{2}{|c|}{ Otros artefactos cerámicos } & 1 tortero, 2 fichas & $\begin{array}{l}1 \text { tortero, } 2 \text { cucharas, } \\
1 \text { escudilla miniatura }\end{array}$ \\
\hline Lítico & \multicolumn{2}{|c|}{$\begin{array}{l}\text { Puntas de proyectil }{ }^{\mathrm{a}} \\
\text { Azadas }^{\mathrm{a}} \\
\text { Otros instrumentos } \\
\text { Manos de moler (plana) } \\
\text { Molinos planos }^{\mathrm{a}} \\
\text { Manos de moler (otras) } \\
\text { Yunques }^{\mathrm{a}} \\
\text { Desechos }^{\mathrm{b}}\end{array}$} & $\begin{array}{c}8 \\
31 \\
13 \\
1 \\
- \\
- \\
- \\
195\end{array}$ & $\begin{array}{c}61 \\
334 \\
12 \\
11 \\
6 \\
6 \\
1 \\
3055\end{array}$ \\
\hline \multicolumn{3}{|l|}{ Cuentas } & 1 de concha & $\begin{array}{c}2 \text { de concha } \\
4 \text { de malaquita }\end{array}$ \\
\hline Otros $^{c}$ & & & $\begin{array}{l}\text { Aguja de } \mathrm{Cu} \text {, } \\
\text { mineral de } \mathrm{Cu}\end{array}$ & $\begin{array}{l}8 \text { gotas de } \mathrm{Cu} \text {, mineral } \\
\text { de } \mathrm{Cu} \text {, trozos de azufre }\end{array}$ \\
\hline
\end{tabular}

Tabla 4. Desechos recuperados en el Recinto 300 de Bajo Laqaya. ${ }^{a}$ Enteras o fragmentos; ${ }^{b}$ Materias primas. Piso: $56 \%$ andesita (fabricación y reactivación de azadas), $36 \%$ sílice gris, $4 \%$ sílices de diversos colores, $3 \%$ obsidiana y $1 \%$ basalto; Relleno: $60 \%$ andesita, $33 \%$ sílice gris, $4 \%$ sílices de color, $2 \%$ obsidiana y $1 \%$ basalto; ${ }^{\mathrm{c}}$ También se recuperaron abundantes huesos de animales cuyo análisis se encuentra en proceso. 
ción de cerámica Mallku (4\%) y Talapaca ${ }^{11}$ $(1.6 \%)$. Si se considera el número mínimo de vasijas (de acuerdo a los bordes), sin embargo, se advierte que las escudillas (en su mayoría Mallku) superan el $50 \%$ de las piezas. Los únicos rasgos presentes son dos huellas de postes (probablemente soportes de la cumbrera para el techo a dos aguas) y un fogón compuesto protegido por un deflector de aire, muy similar en su forma y ubicación a los encontrados en las viviendas (Nielsen 2001b).

\section{Discusión}

La comparación de las dos plazas investigadas revela interesantes similitudes y diferencias. Las primeras abarcan las cuatro expectativas planteadas anteriormente, avalando la conclusión de que algunas de las instituciones descentralizadas y corporativas vigentes al momento de la conquista europea podrían ya estar presentes en algunas regiones circumpuneñas antes de la expansión inca. Por cierto, algunos de estos elementos tienen un origen mucho más antiguo; por ejemplo, las prácticas vinculadas con el culto a los ancestros se remontan al Período Arcaico en el área, como lo sostienen distintos autores (p.e., Rivera 1995; Aschero 2000: 56). En este caso, sin embargo, es la convergencia de las distintas líneas de evidencia en un mismo contexto lo que nos lleva a concluir no sólo que el culto a los antepasados era importante en esta época, sino que estas prácticas se insertaban en un orden político e institucional determinado.

De acuerdo con las expectativas planteadas, estructuras que podrían interpretarse como "monumentos a los antepasados" ocupan un lugar destacado en ambos espacios públicos. En el caso de Los Amarillos se trata de sepulcros sobreelevados, visibles desde gran parte de la plaza y del asentamiento, con su área de congregación o kayana al frente para escenificar las ceremonias correspondientes (Figura 4). Ignoramos si durante estos eventos los cuerpos o sus acompañamientos se

11 El grupo Talapaca comprende vasijas tanto abiertas como cerradas de superficies pulidas, a menudo revestidas, de diversos colores (p.e., naranja, ante, amarillo-crema, rojo borravino). Esta alfarería aparece en Lípez con bajas frecuencias hacia el siglo XIV y cobra mayor popularidad durante los Períodos Inka e Hispano-indígena. extraían, pero suponemos que su contenido podía ser visto desde corta distancia y probablemente fuera renovado o enriquecido con nuevos elementos, lo que justificaría tratarlos como "sepulcros abiertos" (sensu Isbell 1997). Según Guamán Poma (1980 [1615]: 269), en el Collasuyu: "no lo sacan afuera el defunto como Chinchay Suyo a la procición al dicho defunto, cino que le dexan estar metido en su bóbeda, pucullo y le llaman el pueblo de los defuntos" a donde acudían regularmente sus descendientes a darles "de comer y de ueuer", como lo ilustra el dibujo que acompaña este pasaje (Figura 1).

Algunos de los rasgos asociados a los sepulcros del Complejo A darían testimonio de estas actividades de "alimentar" a los difuntos, como las describió Pizarro en el fragmento citado in extenso anteriormente. Evidentemente, la gran estructura de combustión al borde de la plataforma no era un fogón de cocina, sino un contenedor para incinerar cosas en su interior. El virque o vasija de boca ancha para dar chicha al malqui, que describe Pizarro e ilustra Guamán Poma, es una forma característica del repertorio cerámico de la quebrada a partir de $c a .1250$ DC (ver Figura 5c) y no está representada en el componente alfarero Isla-Alfarcito inmediatamente anterior. ${ }^{12} \mathrm{Hemos}$ encontrado sólo uno de estos ejemplares (ver Tabla 3) en el sector oriental de la plataforma, aunque podría haber más, ya que en la fragmentería resulta difícil diferenciarlos de algunos cántaros. También se encuentra el "mortero" con fondo horadado hallado en el cobertizo, que permitiría simultáneamente verter y drenar líquidos. Finalmente, las "cajas" adosadas a la fachada de cada sepulcro ciertamente podrían haber servido para recibir alimentos y bebidas en la forma en que lo representa Guamán Poma. De hecho, la del medio, había sido rellenada con cenizas procedentes de otro lugar, ¿se acercarían los alimentos al pucullo una vez incinerados en la forma en que lo describe Pizarro? Este último autor mencionaba, además, "una piedra redonda en el medio de la plaza... hecha alrededor de una pequeña aber-

12 No pretendemos afirmar que esta forma fue sólo utilizada para dar de beber a los difuntos. Actualmente las vasijas de boca ancha o virques se emplean en varios pasos de la fabricación de la chicha y son objeto de múltiples usos secundarios que requieren de los contenedores gran accesibilidad y capacidad (p.e., amasar pan, lavar ropa). 
tura" donde vertían la chicha una vez que los virques estaban repletos, referencia que no podemos dejar de relacionar con las cajas empotradas al centro del escenario del Complejo A y de la plaza de Bajo Laqaya. En suma, no tenemos certeza de que los rasgos en cuestión fueron usados de este modo, pero sí podemos afirmar que todos los referentes arqueológicos que se derivarían de las prácticas de veneración a los antepasados que describen las fuentes están presentes en el Complejo A.

Como lo señalamos, los sepulcros sobreelevados de Los Amarillos contenían elementos habitualmente tratados como bienes de prestigio. Si nuestra reconstrucción es correcta, sería mejor interpretarlos como "emblemas corporativos" o referentes de identidades colectivas y de los eventos míticos que les dieron origen, antes que relacionarlos con la ostentación del rango individual del difunto o del oficiante, o con el establecimiento de clausuras sociales en base a la manipulación de "riquezas" (Nielsen 2006).

Las chullpas de la plaza de Laqaya, en cambio, no sirvieron de sepulcros, sino que, a juzgar por los hallazgos en la Chullpa 2, probablemente se utilizaron como depósitos para contener productos agrícolas (quinoa) y otros elementos. Sin embargo, como lo argumentamos previamente, no creemos que este uso esté en contradicción con el significado (o función social, si se quiere) de la torre como "monumento al antepasado", sino que sería consistente con la transposición de los conceptos asociados a la ancestralidad a otros campos de la acción. Desde esta perspectiva, sería más acertado pensar en las chullpas como corporalización del propio ancestro, como lo es la huanca (Duviols 1979). Esta forma de ver las cosas explica el empleo de la misma forma arquitectónica para múltiples actividades, un fenómeno que parece haber confundido a los observadores desde la época de la Conquista, generando el interminable debate sobre la "función" de las torres ("¿son sepulcros o son depósitos?"). Si la chullpa es el ancestro, la torre hace (es usada para) lo que -dentro de esta lógica cultural- el ancestro hace, esto es, proteger los campos y las cosechas rodeando los cultivos y almacenando los productos, defender la comunidad rodeando los pucaras (Nielsen 2002) o compartir la fiesta con sus descendientes, recibir sus ofrendas y gobernarlos, que es lo que pensamos que hacían estas tres torres en la plaza de Bajo Laqaya. De acuerdo a esta interpretación, el uso de los "ancestros monumentalizados" como depósitos marcaría diferencias con Los Amarillos en cuanto a ciertas acciones específicas realizadas en la plaza -que en Laqaya podrían incorporar referencias explícitas a la producción agrícola- pero no necesariamente en la vinculación, en los dos casos, del ceremonial público con la veneración a los antepasados y la reproducción de identidades corporativas.

La presencia de múltiples representaciones de los antepasados en ambas plazas es consistente con la expectativa de una espacialidad segmentada en la acción pública, correlativa de las identidades corporativas y poderes descentralizados en los distintos ayllus. La coincidencia de tres monumentos de este tipo en los dos sitios podría relacionarse, a su vez, con la tripartición que algunas fuentes atribuyen a ciertas formaciones políticas andinas (Pärssinen 1992), que se concebían como producto de la unión de tres parcialidades o ayllus -Qollana, Payan y Kayaw en quechua, Araj, Taypi y Manqha en aymara- que mantenían su autonomía política relativa dentro de la "federación". En Laqaya, esta división se replica en los tres edificios que enfrentan a las chullpas desde el lado opuesto de la plaza. Esto podría indicar que otras actividades realizadas en el espacio público, además de aquellas directamente centradas en la representación del ancestro -p.e., la producción y consumo colectivo de bebidas y alimentos- también se estructuraban sobre la base de este esquema segmentario-tripartito.

Como es sabido, la clasificación Qollana-PayanKayaw revestía connotaciones jerárquicas, siendo una instancia particular de un esquema valorativo tripartito que se aplicaba a múltiples dominios semánticos. En los espacios públicos investigados esta dimensión jerárquica se pone materialmente en juego a través del tamaño y ordenamiento de los sepulcros y chullpas. En ambos casos, los monumentos muestran una progresión de tamaño, ubicándose el mayor en el extremo derecho y el menor en el izquierdo, desde el punto de vista del observador situado en la plaza. Esta distribución de derecha a izquierda podría interpretarse como un ejemplo de "triadismo lineal" (Pärssinen 1992: 181) y muestra una notable homología con el caso descrito por el visitador de idolatrías citado en una sección anterior. Como en aquel caso, si el tamaño y posición de los monumentos deno- 
taban el rango de los malquis que contenían o encarnaban -por lo tanto, del ayllu de sus descendientes en la estructura social- es probable que esta jerarquía se encontrara reflejada también en los emblemas que los acompañaban. Desgraciadamente, no podemos verificar esta hipótesis en Los Amarillos, debido a la redepositación del contenido de los sepulcros durante la destrucción del Complejo A.

Si todos estos elementos apuntaban a reproducir en la acción pública la segmentación y las jerarquías corporativas, ¿podemos reconocer elementos que apunten a la integración de las parcialidades en una misma identidad compartida? La plaza, como lugar de reunión de toda la comunidad -y quizás de otras comunidades carentes de espacios públicos semejantes- constituiría una primera materialidad integrativa. En Laqaya la plaza analizada sería la única existente en el sitio en su época y en Los Amarillos, aunque existen otros espacios públicos aparentemente contemporáneos, ninguno de ellos posee la centralidad y configuración del investigado, por lo que es probable que hayan sido destinados a otro tipo de actividades, una hipótesis que deberá ser evaluada mediante futuros trabajos.

Otro elemento que excede el ámbito público, pero tiende igualmente a la constitución de una identidad única para toda la comunidad y otras de la región, es la casa, por lo menos, en el caso del Norte de Lípez. Como lo argumentamos oportunamente (Nielsen 2001), las viviendas de esta época en la región mantienen una sorprendente uniformidad en su forma, tecnología y estructura interna, como si negaran enfáticamente las diferencias (de identidad o de rango) entre los grupos domésticos que las habitaban.

Una tercera materialidad integradora es la cerámica, que se convertiría en un diacrítico de las grandes colectividades regionales. Tanto en Humahuaca como en Lípez, el tránsito al Período de Desarrollos Regionales Tardío a mediados del siglo XIII va acompañado por la aparición de componentes alfareros que incluyen vasijas pintadas con diseños distintivos. En la quebrada, el componente Humahuaca, que reemplaza al IslaAlfarcito del Período de Desarrollos Regionales Temprano (Nielsen 1996b), abarca grupos con diseños (reticulados, espirales, haces de líneas) pintados en negro sobre rojo, ocasionalmente tam- bién blanco. En Lípez el componente alfarero de esta época incluye al estilo Mallku (Arellano y Berberián 1981), integrado fundamentalmente por escudillas bicolores y, con menor frecuencia, pequeños yuros o jarritas. En ambos casos, los materiales pintados están ampliamente distribuidos en los sitios, lo que sugiere que se trata de elementos de circulación irrestricta, al menos dentro de los ámbitos regionales.

La consideración de la función de las vasijas portadoras de estos estilos regionales y su presencia en las plazas nos lleva a la cuarta expectativa, relativa al consumo público. Como lo revela la Figura 5c, las vasijas portadoras de los diseños pintados de esta época en Humahuaca podrían estar afectadas especialmente a este tipo de prácticas: los virques ya mencionados, grandes cántaros para almacenaje de líquidos (¿maduración de chicha?) y yuros para su distribución, fuentes para la exhibición y transporte de grandes raciones y escudillas para su consumo. Carecemos de datos suficientes para reconstruir los detalles de este aspecto de las celebraciones públicas en el caso de Los Amarillos, tarea que deberá aguardar la investigación de los grandes basurales que rodean las plazas del sector central del sitio. La asociación de este espacio con el comensalismo comunitario, sin embargo, está sugerida por los grandes artefactos de molienda y, dentro del Complejo A, por los fogones múltiples y la abundancia de grandes cántaros y fuentes en el sector oriental de la plataforma.

La presencia de los estilos pintados tanto en los espacios públicos como domésticos, que podría revelar, además, la participación de gran parte de las unidades domésticas en la producción de los recursos festivos, nos remite a los vínculos entre el consumo público-ceremonial y cotidiano que Dietler (2000) destaca como aspecto central del comensalismo político. En Laqaya este vínculo está dado también por la semejanza en la forma y estructura interna del Recinto 300 y las viviendas del sitio. Al homologar la plaza con la casa, se verifica la lógica cultural, según la cual la familia, la comunidad y el cosmos se organizan de acuerdo a un modelo común basado en las relaciones de parentesco.

Para concluir quisiera señalar algunas diferencias entre las dos plazas estudiadas que podrían estar revelando, junto a un marco institucional compar- 
tido, importantes variaciones en las prácticas políticas y la distribución del poder entre las dos regiones. El sector central de Los Amarillos posee un diseño espacial jerárquico, plasmado en restricciones a la circulación y asimetrías visuales que revelan una participación diferencial de las personas en las prácticas allí desarrolladas, especialmente las que implicaban el acceso directo a los monumentos funerarios o a su contenido (Nielsen 1995). En términos de la reconstrucción que venimos realizando, si bien las (¿tres?) grandes parcialidades de la comunidad estarían representadas en la plaza a través de sus malquis, no todos los miembros (¿personas? ¿linajes?) dentro de ellas accederían directamente a ellos.

La plaza de Lakaya, en cambio, es un espacio accesible, libre de restricciones y equilibrado en sus componentes, cuya utilización propiciaría una interacción más fluida y simétrica entre los actores. La Figura 9, que muestra la reactivación espontánea de la plaza de Bajo Laqaya por las comunidades vecinas con motivo de la declaración del sitio como Monumento Histórico de Bolivia, ilustra claramente esta interacción "igualitaria" que induce en los participantes el propio diseño de este espacio público. Durante todo el evento, los miembros de la comunidad se dispusieron en un círculo alrededor de la plaza, sucediéndose en el centro (junto a la "caja" central) los eventos programados: sacrificio de llama, challas, discursos, danzas y ejecuciones musicales, culminando con el consumo colectivo de gran cantidad de comidas y bebidas.

El desafío por delante es establecer, a base de la laboriosa consideración de indicadores arqueológicos específicos (p.e., bioarqueológicos, arquitectónicos, en los patrones de consumo de distintos tipos de bienes, en las evidencias de diversas actividades productivas, entre otros), hasta qué punto los contrastes de jerarquías relativas manifiestas en el ceremonial público de las dos comunidades o regiones se replican como desigualdades efectivas en otros campos de acción.

No quisiera concluir este trabajo sin mencionar que, en algún momento del siglo XVI, los tres sepulcros sobreelevados de Los Amarillos y las tres chullpas de la plaza de Laqaya fueron vio-

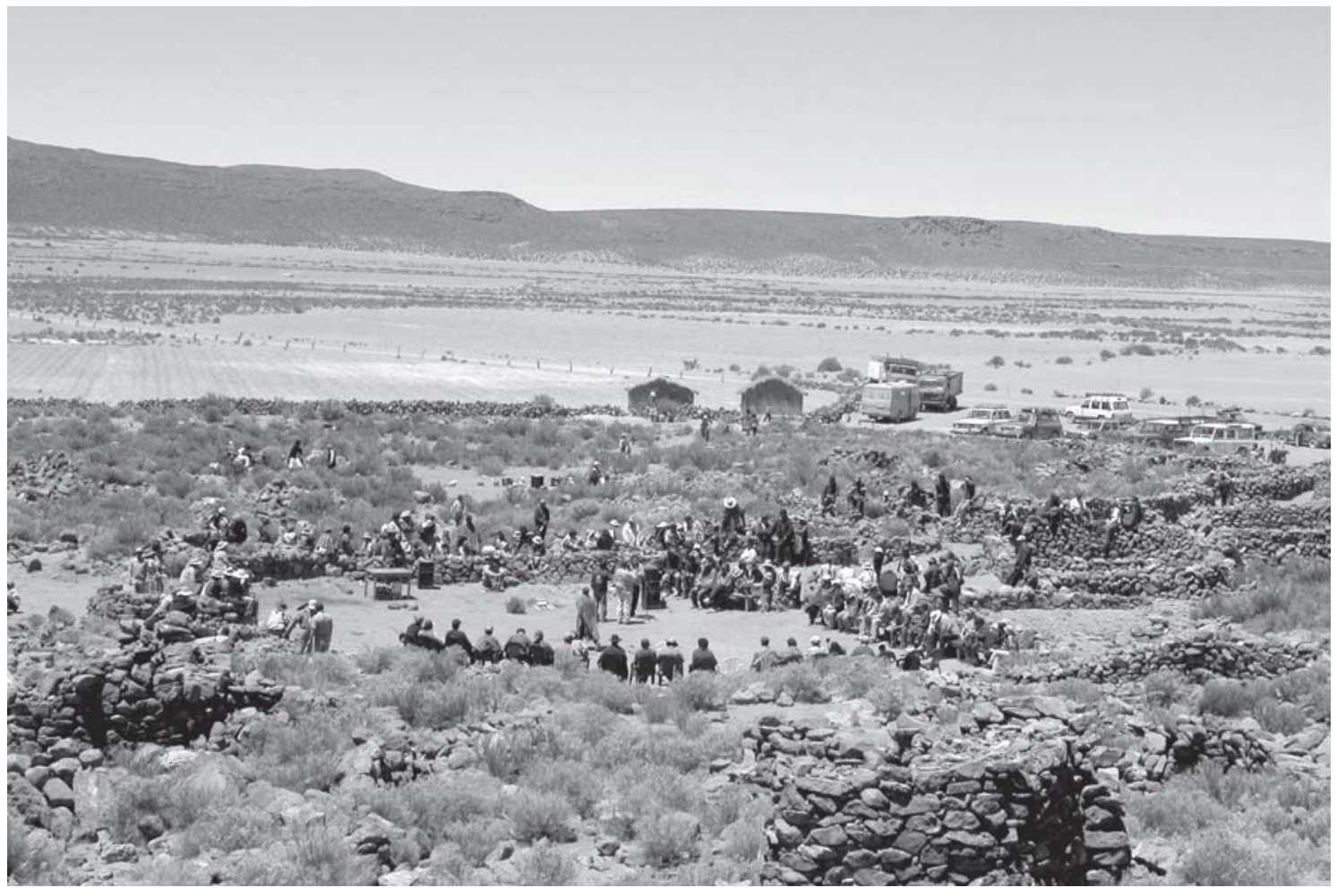

Figura 9. La plaza de Bajo Laqaya durante la celebración de la declaratoria del sitio como Monumento Histórico de Bolivia. 
lentamente destruidos, eventos que parecen haber coincidido con el abandono de importantes sectores de ambos sitios. Como lo hemos propuesto en otras oportunidades (Nielsen y Walker 1999), la coincidencia temporal de estos eventos con la expansión incaica sugiere una estrecha relación entre todos estos hechos. Si esta conclusión es correcta, el establecimiento del Tawantinsuyu no sólo pudo implicar cambios en la distribución de poderes en los escenarios locales, sino, además, una reformulación de las memorias colectivas regionales y del propio rol de la ancestralidad y el parentesco como principios de legitimidad para el ejercicio del poder político. La awkaipata inca pone en primer plano la institucionalidad del Estado, no los antepasados locales. El poder político sigue recurriendo a discursos sobre la ancestralidad, pero se trata de discursos panandinos, en los que el monarca, como descendiente directo del sol -por lo tanto, antepasado de los ancestros locales- ocupa una posición superior en la jerarquía genealógico-política. Esto nos lleva a terminar planteando preguntas para la etnohistoria: ¿Qué papel jugaban los antepasados locales en las formaciones políticas circumpuneñas del siglo XVI? ¿Sobrevivieron fragmentos de aquella memoria al olvido incaico?

Agradecimientos Quiero agradecer a los especialistas que tomaron a su cargo el análisis de distintos materiales recuperados en Los Amarillos: Julio Avalos (lítico), Pablo Mercolli (fauna), Verónica Seldes (huesos humanos), Nelly Vargas Rodríguez (restos malacológicos), Alejandra Wurschmidt (restos macrobotánicos) y Silvina Escalante (maderas). Agradezco también a María M. Vázquez por su asistencia en el análisis (cuentas, artefactos de hueso, cerámica) y en la confección de las figuras. Finalmente, mi gratitud a las comunidades de Yakoraite, Santiago K y Santiago Chuvica por su hospitalidad y sostenido apoyo a nuestras investigaciones. El trabajo se benefició mucho con una atenta lectura de José Luis Martínez, quien evidentemente no es responsable de mis errores.

\section{REFERENCIAS CITADAS}

ALBARRACIN, J., 1996. Tiwanaku settlement system: The integration of nested hierarchies in the lower Tiwanaku valley. Latin American Antiquity 7: 183-210.

- 1997. Tiwanaku: Arqueología regional y dinámica segmentaria. Plural, La Paz.

ALDUNATE, C. y V. CASTRO, 1981. Las chullpas de Toconce. Kultrún, Santiago.

ARELLANO, J. y E. BERBERIAN, 1981. Mallku: El señorío post-Tiwanaku del altiplano sur de Bolivia (Provincias Nor y Sur Lípez-Depto. de Potosí). Bulletin de l'Institut Français d'Etudes Andines 10 (1-2): 51-84.

ARRIAGA, P. J., 1968 [1621]. The extirpation of idolatry in Peru. University of Kentucky Press, Lexington.

ASCHERO, C., 2000. El poblamiento del territorio. Nueva Historia argentina, vol. 1, M. Tarragó (Ed.), pp. 17-59. Editorial Sudamericana, Buenos Aires.

BLANTON, R. E., 1998. Beyond centralization: Steps toward a theory of egalitarian behavior in Archaic States. En Archaic States, G. Feinman y J. Marcus (Eds.), pp. 135172. School of American Research Press, Santa Fe.

BLANTON, R., G. FEINMAN, S. KOWALEWSKI y P. PEREGRINE, 1996. A dual-processual theory for the evolution of Mesoamerican civilization. Current Anthropology 37: 1-14.
BOURDIEU, P., 1980. Distinction: A social critique of the judgement of taste. Harvard University Press, Cambridge.

1991. Political representation: Elements for a theory of the political field. En Language and symbolic power, J. Thompson (Ed.), pp. 171-202. Harvard University Press, Cambridge.

CASTRO, V., C. ALDUNATE y J. BERENGUER, 1984. Orígenes altiplánicos de la Fase Toconce. Estudios Atacameños 7: 209-235.

CIEZA DE LEON, P., 1996 [1553]. Crónica del Perú. Academia Nacional de la Historia, Lima.

DIETLER, M., 2000. Theorizing the feast: Rituals of consumption, commensal politics, and power in African contexts. En Feasts: Archaeological and ethnographic perspectives on food, politics, and power, M. Dietler y B. Hayden (Eds.), pp. 65-114. Smithsonian Institution Press, Washington D. C.

DOUGLAS, M., 1986. How institutions think. Syracuse University Press, Syracuse.

DUVIOLS, P. 1979. Un symbolisme de l'occupation, de l'amenagement et de l'exploitation de l'espace: Le monolithe 'huanca' et sa fonction dans les Andes préhispaniques. L’Homme XIX (2): 7-31. 
EARLE, T., 1997. How chiefs come to power: The political economy in prehistory. Stanford University Press, Stanford.

FEINMAN, G., 2000. Corporate/network: New perspectives on modes of political action and the Puebloan Southwest. En Social theory in archaeology, M. Schiffer (Ed.), pp. 31-51. University of Utah Press, Salt Lake City.

GUAMAN POMA DE AYALA, F., 1980 [1615]. Nueva crónica y buen gobierno. Siglo XXI, México D. F.

HAYDEN, B., 2000. Fabulous feasts: A prolegomenon to the importance of feasting. En Feasts: Archaeological and ethnographic perspectives on food, politics, and power, M. Dietler y B. Hayden (Eds.), pp. 23-64. Smithsonian Institution Press, Washington D. C.

2001. Richman, poorman, beggarman, chief: The dynamics of social inequality. En Archaeology at the millennium: A sourcebook, G. Feinman y D. Price (Eds.), pp. 231272. Kluwer/Plenum, Nueva York.

ISBELL, W., 1997. Mummies and mortuary monuments: A postprocessual prehistory of Central Andean social organization. University of Texas Press, Austin.

IZKO, X., 1992. La doble frontera: Ecología, política y ritual en el Altiplano Central. Hisbol, La Paz.

KAULICKE, P., 2001. Vivir con los ancestros en el antiguo Perú. En La memoria de los ancestros, L. Millones y W. Kapsoli (Eds.), pp. 25-61. Editorial Universitaria, Lima.

KUPER, A., 1982. Lineage theory: A critical retrospect. Annual Review of Anthropology 11: 71-95.

LECOQ, P., 1999. Uyuni préhispanique. BAR International Series 798, Oxford.

MADRAZO, G. y M. OTONELLO, 1966. Tipos de instalación prehispánica en la región de la Puna y su borde. Monografías 1, Museo Etnográfico Municipal "Dámaso Arce", Olavarría.

MARTINEZ, G., 1989. Espacio y pensamiento. I: Andes Meridionales. Hisbol, La Paz.

MARTINEZ, J. L., 1995. Autoridades en los Andes, los atributos del Señor. Pontificia Universidad Católica del Perú, Lima.

MCANNANY, P., 1995. Living with the ancestors: Kinship and kingship in ancient Maya society. University of Texas Press, Austin.

MCCORMAC, F.G., A.G. HOGG, P.G. BLACKWELL, C.E. BUCK, T.F.G. HIGHAM y P.J. REIMER, 2004. SHCal04 Southern hemisphere calibration 0-1000 cal BP. Radiocarbon 46: 1087-1092.

MCGUIRE, R. H., 1983. Breaking down cultural complexity: Inequality and heterogeneity. En Advances in archaeological method and theory, vol. 6, M. Schiffer (Ed.), pp. 91-142. Academic Press, Nueva York.
MCGUIRE, R. H. y D. J. SAITTA, 1996. Although they have petty captains, they obey them badly: The dialectics of prehispanic Western Pueblo social organization. American Antiquity 61: 197-216.

MESKELL, L., 2004. Object worlds in Ancient Egypt: Material biographies past and present. Berg, Oxford.

MOORE, J. D., 1989. Pre-Hispanic beer in coastal Peru: Technology and social context of prehistoric production. American Anthropologist 91: 682-695.

MURRA, J. V., 1975. Formaciones políticas y económicas del mundo andino. Instituto de Estudios Peruanos, Lima.

NIELSEN, A., 1995. Architectural performance and the reproduction of social power. En Expanding archaeology, J. M. Skibo, W. H. Walker y A. Nielsen (Eds.), pp. 4766. University of Utah Press, Salt Lake City.

-1996a. Estructuras y jerarquías de asentamiento en Humahuaca (Jujuy, Argentina) en vísperas de la invasión europea. En XXV Aniversario del Museo Arqueológico Eduardo Casanova, pp. 99-109. Instituto Interdisciplinario Tilcara, Tilcara.

-1996b. Demografía y cambio social en la quebrada de Humahuaca (Jujuy, Argentina) ca. 700-1535 DC. Relaciones de la Sociedad Argentina de Antropología XXI: 307-385.

-1997. Aproximaciones arqueológicas y etnohistóricas a la diversidad cultural tardía en el Altiplano de Lípez. Contribución Arqueológica 5: 95-129.

2001. Evolución del espacio doméstico en el Norte de Lípez (Potosí, Bolivia) ca. 900-1700 DC. Estudios Atacameños 21: 41-61.

2002. Asentamientos, conflicto y cambio social en el altiplano de Lípez (Potosí, Bolivia). Revista Española de Antropología Americana 32: 179-205.

2006. Celebrando con los antepasados: Arqueología del espacio público en Los Amarillos, quebrada de Humahuaca, Jujuy, Argentina. Mallku Ediciones, Buenos Aires.

NIELSEN, A. y W. H. WALKER, 1999. Conquista ritual y dominación política en el Tawantinsuyu: El caso de Los Amarillos (Jujuy, Argentina). En Sed non satiata: Teoría social en la arqueología latinoamericana contemporánea, A. Zarankin y F. Acuto (Eds.), pp. 153-169. Ediciones del Tridente, Buenos Aires.

PÄRSSINEN, M. 1992. Tawantinsuyu: The Inca State and its political organization. Finish Historical Society, Helsinki.

PEASE, F., 1992. Curacas, reciprocidad y riqueza. Pontificia Universidad Católica del Perú, Lima.

PLATT, T., 1987. Entre ch'axwa y muxsa: Para una historia del pensamiento político aymara. En Tres reflexiones sobre el pensamiento andino, J. Medina (Ed.), pp. 61-132. Hisbol, La Paz. 
REAL ACADEMIA ESPAÑOLA, 2001. Diccionario de la lengua española (22 ${ }^{\mathrm{a}}$ edición). Grupo Editorial Planeta, Buenos Aires.

RASNAKE, R., 1989. Autoridad y poder en los Andes: Los Kuraqkuna de Yura. Hisbol, La Paz.

RIVERA, M., 1995. The preceramic Chinchorro mummy complex of northern Chile: Context, style, and purpose. En Tombs for the living: Andean mortuary practices, T. Dillehay (Ed.), pp. 43-77. Dumbarton Oaks, Washington D. C.
SAIGNES, T., 1993. Borrachera y memoria: La experiencia de lo sagrado en los Andes. Hisbol-IFEA, La Paz.

SCHIAPPACASSE, V., V. CASTRO y H. NIEMEYER, 1989. Los Desarrollos Regionales en el Norte Grande (10001400 DC). En Culturas de Chile: Prehistoria. Desde sus orígenes a los albores de la Conquista, J. Hidalgo, V. Schiappacasse, H. Niemeyer, C. Aldunate e I. Solimano (Eds.), pp. 181-220. Editorial Andrés Bello, Santiago. 